\title{
Factors controlling black carbon distribution in the Arctic
}

\author{
Ling $\mathbf{Q i}^{1,2}$, Qinbin $\mathbf{L i}^{1,2}$, Yinrui $\mathbf{L i}^{3}$,a , and Cenlin $\mathbf{H e}^{1,2}$ \\ ${ }^{1}$ Department of Atmospheric and Oceanic Sciences, University of California, Los Angeles, CA, USA \\ ${ }^{2}$ Joint Institute for Regional Earth System Science and Engineering, University of California, Los Angeles, CA, USA \\ ${ }^{3}$ School of Physics, Peking University, Beijing, China \\ ${ }^{a}$ now at: Department of Atmospheric Sciences, University of Illinois Urbana-Champaign, Champaign, IL, USA
}

Correspondence to: Ling Qi (qiling@atmos.ucla.edu)

Received: 5 August 2016 - Published in Atmos. Chem. Phys. Discuss.: 10 August 2016

Revised: 16 December 2016 - Accepted: 21 December 2016 - Published: 23 January 2017

\begin{abstract}
We investigate the sensitivity of black carbon (BC) in the Arctic, including $\mathrm{BC}$ concentration in snow $\left(\mathrm{BC}_{\text {snow }}\right.$, $\left.\mathrm{ng} \mathrm{g}^{-1}\right)$ and surface air $\left(\mathrm{BC}_{\text {air }}, \mathrm{ng} \mathrm{m}^{-3}\right)$, as well as emissions, dry deposition, and wet scavenging using the global threedimensional (3-D) chemical transport model (CTM) GEOSChem. We find that the model underestimates $\mathrm{BC}_{\text {snow }}$ in the Arctic by $40 \%$ on average (median $=11.8 \mathrm{ng} \mathrm{g}^{-1}$ ). Natural gas flaring substantially increases total $\mathrm{BC}$ emissions in the Arctic (by $\sim 70 \%$ ). The flaring emissions lead to up to $49 \%$ increases $\left(0.1-8.5 \mathrm{ng} \mathrm{g}^{-1}\right)$ in Arctic $\mathrm{BC}_{\text {snow }}$, dramatically improving model comparison with observations (50\% reduction in discrepancy) near flaring source regions (the western side of the extreme north of Russia). Ample observations suggest that $\mathrm{BC}$ dry deposition velocities over snow and ice in current CTMs $\left(0.03 \mathrm{~cm} \mathrm{~s}^{-1}\right.$ in the GEOS-Chem) are too small. We apply the resistance-in-series method to compute a dry deposition velocity $\left(v_{\mathrm{d}}\right)$ that varies with local meteorological and surface conditions. The resulting velocity is significantly larger and varies by a factor of 8 in the Arctic $\left(0.03-0.24 \mathrm{~cm} \mathrm{~s}^{-1}\right)$, which increases the fraction of dry to total $\mathrm{BC}$ deposition (16 to $25 \%$ ) yet leaves the total $\mathrm{BC}$ deposition and $\mathrm{BC}_{\text {snow }}$ in the Arctic unchanged. This is largely explained by the offsetting higher dry and lower wet deposition fluxes. Additionally, we account for the effect of the Wegener-Bergeron-Findeisen (WBF) process in mixed-phase clouds, which releases $\mathrm{BC}$ particles from condensed phases (water drops and ice crystals) back to the interstitial air and thereby substantially reduces the scavenging efficiency of clouds for BC (by $43-76 \%$ in the Arctic). The resulting $\mathrm{BC}_{\text {snow }}$ is up to $80 \%$ higher, $\mathrm{BC}$ loading is considerably larger (from 0.25 to $0.43 \mathrm{mg} \mathrm{m}^{-2}$ ), and $\mathrm{BC}$ lifetime is markedly prolonged (from 9 to 16 days) in the Arc-
\end{abstract}

tic. Overall, flaring emissions increase $\mathrm{BC}_{\mathrm{air}}$ in the Arctic (by $\sim 20 \mathrm{ng} \mathrm{m}^{-3}$ ), the updated $v_{\mathrm{d}}$ more than halves $\mathrm{BC}_{\text {air }}$ (by $\sim 20 \mathrm{ng} \mathrm{m}^{-3}$ ), and the WBF effect increases $\mathrm{BC}_{\text {air }}$ by 25 $70 \%$ during winter and early spring. The resulting model simulation of $\mathrm{BC}_{\mathrm{snow}}$ is substantially improved (within $10 \%$ of the observations) and the discrepancies of $\mathrm{BC}_{\mathrm{air}}$ are much smaller during the snow season at Barrow, Alert, and Summit (from $-67--47 \%$ to $-46-3 \%$ ). Our results point toward an urgent need for better characterization of flaring emissions of BC (e.g., the emission factors, temporal, and spatial distribution), extensive measurements of both the dry deposition of $\mathrm{BC}$ over snow and ice, and the scavenging efficiency of $\mathrm{BC}$ in mixed-phase clouds. In addition, we find that the poorly constrained precipitation in the Arctic may introduce large uncertainties in estimating $\mathrm{BC}_{\text {snow }}$. Doubling precipitation introduces a positive bias approximately as large as the overall effects of flaring emissions and the WBF effect; halving precipitation produces a similarly large negative bias.

\section{Introduction}

Black carbon (BC; loosely also known as soot), light absorbing refractory carbonaceous aerosol, influences climate through direct absorption of solar radiation, semi-direct cloud effects, indirect cloud effects, and snow-albedo effect (Bond et al., 2013; IPCC, 2014). BC deposited on surfaces with high albedo, such as snow and ice, reduces surface albedo (the snow-albedo effect), increases surface solar heating, and accelerates snow and ice melting (Flanner et al., 2007, 2012; He et al., 2014b; Liou et al., 2014). This snow-albedo feedback leads to enhanced $\mathrm{BC}$ radiative forc- 
ing (Bond et al., 2013, and references therein). Warren and Wiscombe (1985) highlighted the climate effect of fallen soot from "smokes" for a nuclear war scenario, which reduced the surface reflectivity of snow and sea ice in the Arctic. Measurements by Clarke and Noone (1985) showed that there was ample amount of $\mathrm{BC}$ in the Arctic snow to exert climate impacts in the region. Using observations of $\mathrm{BC}_{\text {snow }}$, Hansen and Nazarenko (2004) quantified, for the first time, the albedo reduction due to $\mathrm{BC}$ deposition on snow and ice ( $2.5 \%$ on average) across the Arctic. The snow-albedo effect of $\mathrm{BC}$ in the Arctic has since received wide attention. Numerous studies have examined the snow-albedo change in this region due to BC deposition (Jacobson, 2004; Marks and King, 2013; Namazi et al., 2015; Tedesco et al., 2016) and estimated the associated surface $\mathrm{BC}$ snow-albedo radiative forcing to be substantial $\left(0.024-0.39 \mathrm{~W} \mathrm{~m}^{-2}\right)$ in the Arctic (Bond et al., 2013, and references therein; Flanner, 2013; Jiao et al., 2014; Namazi et al., 2015), comparable to the forcing of tropospheric ozone in springtime Arctic $\left(0.34 \mathrm{~W} \mathrm{~m}^{-2}\right.$, Quinn et al., 2008). BC deposited on snow and ice is likely to be an important reason for unexpectedly rapid sea-ice shrinkage in the Arctic (Koch et al., 2009; Goldenson et al., 2012; Stroeve et al., 2012). Widespread surface melting of the Greenland Ice Sheet was attributed to rising temperatures and reductions in surface albedo resulting from deposition of BC from Northern Hemisphere forest fires (Keegan et al., 2014; Tedesco et al., 2016).

To better constrain the radiative forcing and the associated uncertainties of the BC snow-albedo effect in the Arctic, it is imperative to improve the diagnosis and prediction of $\mathrm{BC}_{\text {snow }}$ in the region. Previous studies found large discrepancies between modeled and observed $\mathrm{BC}_{\text {snow }}$ (up to a factor of 6) in the Arctic (e.g., Flanner et al., 2007; Koch et al., 2009). A comprehensive survey of $\mathrm{BC}_{\text {snow }}$ observations across the Arctic ( $\sim 1000$ snow samples) by Doherty et al. (2010) provided a unique opportunity to constrain $\mathrm{BC}_{\text {snow }}$ in the region. Bond et al. (2013) compared results of $\mathrm{BC}_{\text {snow }}$ from the Community Atmospheric Model version 3.1 (CAM3.1) (Flanner et al., 2009) and the Goddard Institute of Space Studies (GISS) model (Koch et al., 2009) with the observations from Doherty et al. (2010), averaged over the eight Arctic sub-regions (Fig. 1) as defined by Doherty et al. (2010). The resulting ratio of modeled to observed $\mathrm{BC}_{\text {snow }}$ (sub-regional means) was 0.6-3.4 for CAM3.1 and 0.3-1.6 for GISS. Jiao et al. (2014) found large discrepancies in $\mathrm{BC}_{\text {snow }}$ (up to a factor of 6 ) between results from the Aerosol Comparisons between Observations and Models (AeroCom; http://aerocom.met.no/) and the Doherty et al. (2010) observations. They also found large variations in $\mathrm{BC}$ deposition fluxes among the AeroCom models. Jiao et al. (2014) further pointed out that BC transport and deposition processes are more important for differences in simulated $\mathrm{BC}_{\text {snow }}$ than differences in snow meltwater scavenging rates or emissions in models.
Studies have shown that Arctic atmospheric BC on average cools the surface due to surface dimming, while BC in the lower troposphere warms the surface with a climate sensitivity (surface temperature change per unit forcing) of $2.8 \pm 0.5 \mathrm{~K} \mathrm{~W}^{-1} \mathrm{~m}^{2}$ due to low clouds and sea-ice feedbacks that amplify the warming (e.g., Flanner, 2013). This sensitivity is a factor of 2 larger than that of the BC snowalbedo feedback $\left(1.4 \pm 0.7 \mathrm{~K} \mathrm{~W}^{-1} \mathrm{~m}^{2}\right.$, Flanner, 2013), a factor of 4 larger than that of $\mathrm{CO}_{2}\left(0.69 \mathrm{~K} \mathrm{~W}^{-1} \mathrm{~m}^{2}\right.$, Bond et al., 2013), and much larger than that of tropospheric ozone $\left(0.2 \mathrm{~K} \mathrm{~W}^{-1} \mathrm{~m}^{2}\right.$; Shindell and Faluvegi, 2009). However, estimates of $\mathrm{BC}_{\mathrm{air}}$ in the Arctic are associated with large uncertainties (Textor et al., 2006, 2007; Koch et al., 2009; Liu et al., 2011; Browse et al., 2012; Sharma et al., 2013). In general, current models successfully reproduced the decadal declining trends observed at the surface sites Barrow, Alert, and Zeppelin (Sharma et al., 2004, 2006, 2013; Eleftheriadis et al., 2009), but failed to reproduce the seasonal cycles of $\mathrm{BC}_{\mathrm{air}}$ observed at the aforementioned sites, with large underestimates during the Arctic haze season (Textor et al., 2006, 2007; Koch et al., 2009; Liu et al., 2011; Browse et al., 2012; Sharma et al., 2013; Eckhardt et al., 2015). Specifically, mean $\mathrm{BC}_{\text {air }}$ during January to March was underestimated by about a factor of 2 for the mean of all models, although the discrepancy is up to a factor of 27 for individual models (Eckhardt et al., 2015). The low biases are likely due to uncertainties associated with estimates of $\mathrm{BC}$ emissions in Russia (Huang et al., 2015), treatments of BC aging in the models (Liu et al., 2011; He et al., 2016), excessive dry deposition of BC (Huang et al., 2010; Liu et al., 2011), wet scavenging of BC (Koch et al., 2009; Huang et al., 2010; Bourgeois and Bey, 2011; Liu et al., 2011), or overly efficient vertical mixing (Koch et al., 2009). Studies (Wang et al., 2011; Huang et al., 2015) have pointed out that the low biases of $\mathrm{BC}_{\mathrm{air}}$ during the Arctic haze season are partially due to uncertainties in the estimates of BC emissions in Russia, resulted from biases in both $\mathrm{BC}$ emission rates and spatial distributions. A likely missing source of $\mathrm{BC}$ emissions in Russia is natural-gas-flaring emissions, most of which cluster in the western side of the extreme north of Russia (Stohl et al., 2013). Although in totality gas-flaring emissions are a rather small fraction of global BC emissions, their proximity to the Arctic can conceivably result in a disproportionately large impact. Dry deposition of BC on snow and ice is yet another poorly understood and quantified process. Observations show that $v_{\mathrm{d}}$ over snow- and ice-covered surfaces vary by orders of magnitude $\left(0.01-1.52 \mathrm{~cm} \mathrm{~s}^{-1}\right.$; Hillamo et al., 1993; Bergin et al., 1995; Nilsson and Rannik, 2001; Gronlund et al., 2002; Held et al., 2011; Wang et al., 2014). Current chemical transport models (CTMs) tend to assume uniform and low dry deposition velocities over such surfaces to capture the high surface $\mathrm{BC}_{\mathrm{air}}$ during the Arctic haze season (Wang et al., 2011; Sharma et al., 2013). For instance, Wang et al. (2011) used a uniform $v_{\mathrm{d}}$ of $0.03 \mathrm{~cm} \mathrm{~s}^{-1}$ over snow and ice and found a better comparison with $\mathrm{BC}_{\text {air }}$ mea- 


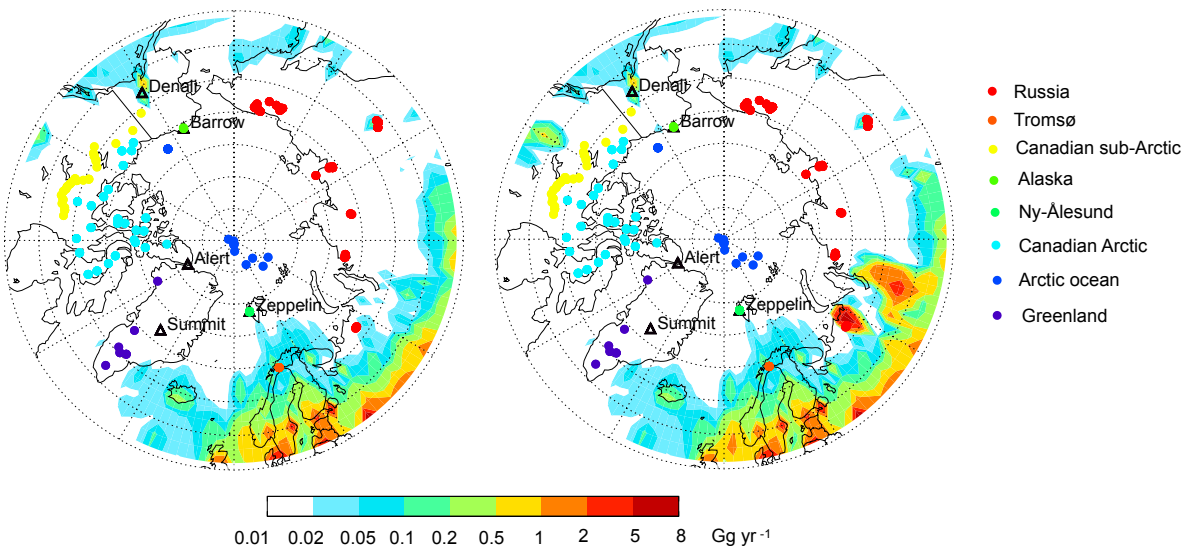

Figure 1. Annual BC emissions $\left(\mathrm{Gg} \mathrm{yr}^{-1}\right)$ in the Arctic in experiment A (left panel) and experiments B, C, and D (right panel). Also shown are in situ BC measurement stations (open triangles) and snow sample locations (solid circles). The eight sub-regions of the Arctic as defined in Doherty et al. (2010) are color-coded. See text for details.

surements during the Arctic haze season. However, this value is probably too low for snow-covered land surfaces with larger roughness length. Additionally, observations show that $\mathrm{BC}$ scavenging efficiency in clouds varies from 0.06 to 0.7 depending on liquid water contents, temperature, and ice mass fraction because of the Wegener-Bergeron-Findeisen (WBF) process in mixed-phase clouds (Cozic et al., 2007; Verheggen et al., 2007). However, in most of the current AeroCom models, BC scavenging is poorly treated (Wang et al., 2011; Bourgeois and Bey, 2011) or entirely missing (Liu et al., 2011) in mixed-phase clouds, which cover the Arctic in $\sim 40 \%$ of the time through a whole year (Zhang et al., 2010). For example, BC scavenging in mixed-phase clouds was treated the same as that in warm clouds in the GEOSChem (Wang et al., 2011). In ECHAM5-HAM2, BC scavenging efficiency in mixed-phase clouds was set up as 0.06 , the lowest observed value in those clouds (Bourgeois and Bey, 2011).

Constraining individual processes of $\mathrm{BC}$ is often challenging. Therefore, our focus is more geared toward highlighting missing processes or ones that were previously unaccounted for in governing $\mathrm{BC}$ in the Arctic, particularly $\mathrm{BC}$ deposition in the region. We first examine and incorporate gas-flaring emissions of $\mathrm{BC}$, which was missing in previous emission estimates yet account for a large fraction of $\mathrm{BC}$ emissions in the Arctic as suggested by Stohl et al. (2013) (Sect. 4.1). We then discuss and improve the simulation of $v_{\mathrm{d}}$ for $\mathrm{BC}$ over snow and ice, which varies by orders of magnitude but was treated as a uniform value by previous studies (Sect. 4.2). We then analyze $\mathrm{BC}$ wet scavenging efficiency in mixed-phase clouds accounting for effects of WBF (Sect. 4.3). Finally, we estimated the sensitivity of $\mathrm{BC}_{\text {snow }}$ to precipitation in the Arctic (Sect. 4.4). We also use $\mathrm{BC}_{\mathrm{air}}$ as an additional constraint of these simulations.

\section{BC observations in the Arctic}

\subsection{Measurements of $\mathrm{BC}$ in snow}

The most comprehensive measurements of $\mathrm{BC}_{\text {snow }}$ were in eight sub-regions in the Arctic: Alaska, Arctic Ocean, Canadian Arctic, Canadian sub-Arctic, Greenland, Russia, NyÅlesund, and Troms $\varnothing$, mostly from March to May during 2005-2009 (Doherty et al., 2010; data available at http:// www.atmos.washington.edu/sootinsnow/). Samples were for full snowpack depth and the sampling sites are shown in Fig. 1 (color-coded by the sub-regions). These observations provide a reasonable constraint on Arctic-wide annual mean radiative effect from BC deposited in snow (Jiao et al., 2014).

Doherty et al. (2010) measured the light absorption of impurity in snow samples using the integrating sphere/integrating sandwich optical method and derived equivalent, maximum, and estimated $\mathrm{BC}_{\text {snow }}$ using the wavelength-dependent absorption of $\mathrm{BC}$ and non-BC fractions (Doherty et al., 2010). We use here the estimated $\mathrm{BC}_{\text {snow }}$. The largest sources of uncertainty stem from uncertainties of $\mathrm{BC}$ mass absorption cross section (MAC), BC absorption Ångstrom exponent ( $\left.\AA_{\mathrm{BC}}\right)$, and non-BC absorption Ångstrom exponent $\left(\AA_{\text {non }}-\mathrm{BC}\right)$ constituents. Doherty et al. (2010) used $\mathrm{MAC}=6.0 \mathrm{mg}^{2} \mathrm{~g}^{-1}$ (at $500 \mathrm{~nm}$ ), the MAC of their calibration filters. Using $\mathrm{MAC}=7.5 \mathrm{mg}^{2} \mathrm{~g}^{-1}$ (at $500 \mathrm{~nm}$ ) as recommended by Bond and Bergstrom (2006) would increase the estimated $\mathrm{BC}_{\text {snow }}$ by $\sim 25 \%$. Doherty et al. (2010) used $\AA_{B C}=1.0$ (range of $\left.0.8-1.9\right)$ and $\AA_{\text {non- }} \mathrm{BC}=$ 5.0 (range of 3.5-7.0) in their derivation and estimated a $50 \%$ error in the estimated $\mathrm{BC}_{\text {snow. }}$. Additional uncertainties include instrumental uncertainty $(\leq 11 \%)$, under-catch correction $( \pm 15 \%)$, and loss of aerosol to plastic flakes in the collection bags $(-20 \%)$ for samples from western Russia and the Canadian sub-Arctic. The overall uncertainty of the estimated $\mathrm{BC}_{\text {snow }}$ is $<60 \%$. 
Table 1. Measurements of BC in surface air in the Arctic.

\begin{tabular}{llll}
\hline Station & $\begin{array}{l}\text { Temporal } \\
\text { frequency }\end{array}$ & $\begin{array}{l}\text { Data } \\
\text { availability* }\end{array}$ & References \\
\hline $\begin{array}{l}\text { Denali } \\
\left(63.7^{\circ} \mathrm{N}, 149.0^{\circ} \mathrm{W} ; 0.66 \mathrm{~km}\right)\end{array}$ & $\begin{array}{l}24 \mathrm{~h} \text { average } \\
\text { every } 3 \text { days }\end{array}$ & $91 \%$ & Malm et al. (1994) \\
$\begin{array}{l}\text { Barrow } \\
\left(71.3^{\circ} \mathrm{N}, 156.6^{\circ} \mathrm{W} ; 0.01 \mathrm{~km}\right)\end{array}$ & $1 \mathrm{~h}$ & $86 \%$ & Bodhaine (1989) \\
$\begin{array}{l}\text { Alert } \\
\left(82.3^{\circ} \mathrm{N}, 62.3^{\circ} \mathrm{W} ; 0.21 \mathrm{~km}\right)\end{array}$ & $30 \mathrm{~min}$ & $79 \%$ & Sharma et al. (2004) \\
$\begin{array}{l}\text { Zeppelin } \\
\left(79^{\circ} \mathrm{N}, 12^{\circ} \mathrm{E} ; 0.47 \mathrm{~km}\right)\end{array}$ & $5 \mathrm{~min}$ & $95 \%$ & Eleftheriadis et al. (2009) \\
$\begin{array}{l}\text { Summit } \\
\left(72.6^{\circ} \mathrm{N}, 38.5^{\circ} \mathrm{W} ; 3.22 \mathrm{~km}\right)\end{array}$ & & Delene and Ogren (2002) \\
\hline
\end{tabular}

* Ratio of available to total data (including available and missing data).

\subsection{Measurements of $\mathrm{BC}$ in surface air}

In situ measurements of $\mathrm{BC}_{\mathrm{air}}$ from 2007 to 2009 are available at five sites within the Arctic Circle (Fig. 1): Denali, $\mathrm{AL}\left(63.7^{\circ} \mathrm{N}, 149.0^{\circ} \mathrm{W} ; 0.66 \mathrm{~km}\right.$ above mean sea level, a.s.1.), Barrow, $\operatorname{AL}\left(71.3^{\circ} \mathrm{N}, 156.6^{\circ} \mathrm{W} ; 0.01 \mathrm{~km}\right.$ a.s.1.), Alert, Canada $\left(82.3^{\circ} \mathrm{N}, 62.3^{\circ} \mathrm{W} ; 0.21 \mathrm{~km}\right.$ a.s.1. $)$, Summit, Greenland $\left(72.6^{\circ} \mathrm{N}, 38.5^{\circ} \mathrm{W} ; 3.22 \mathrm{~km}\right.$ a.s.1.), and Zeppelin, Norway $\left(79^{\circ} \mathrm{N}, 12^{\circ} \mathrm{E} ; 0.47 \mathrm{~km}\right.$ a.s.1.). Data descriptions are shown in Table 1. Denali is part of the Interagency Monitoring of PROtected Visual Environment (IMPROVE) network (Malm et al., 1994; data available at http://vista.cira. colostate.edu/improve/). IMPROVE measurements are made every 3 days and $24 \mathrm{~h}$ averages are reported. Thermal Optical Reflectance (TOR) combustion method is used based on the preferential oxidation of organic carbon (OC) and BC at different temperatures (Chow et al., 2004). BC-like products of OC pyrolysis can lead to an overestimate of the BC mass. The uncertainties of the TOR method are difficult to quantify (Park et al., 2003; Chow et al., 1993).

Barrow is part of the NOAA Global Monitoring Division (GMD) network, where BC light absorption coefficients have been measured from a particle soot absorption photometer (PSAP) since 1997 (Bond et al., 1999; Delene and Ogren, 2002; data available at http://www.esrl.noaa.gov/gmd/aero/ net/). PSAP measures the change in light transmission at three wavelengths $(467,530$ and $660 \mathrm{~nm})$ through a filter on which particles are collected. We used the measurements at $530 \mathrm{~nm}$ in this study. Site Barrow is about $8 \mathrm{~km}$ northeast of the village of Barrow and is less than $3 \mathrm{~km}$ southeast of the Arctic Ocean. Given that the site has a prevailing eastnortheast wind off the Beaufort Sea, it receives minimal influence from local anthropogenic emissions and is strongly affected by weather in the central Arctic.

$\mathrm{BC}_{\mathrm{air}}$ at Alert were measured using an aethalometer model AE-6 with one wavelength operated by Environment Canada (Sharma et al., 2004, 2006, 2013; data available at http: //www.ec.gc.ca/). The instruments measure the attenuation of light transmitted through particles that accumulate on a quartz fiber filter at $880 \mathrm{~nm}$. Alert, located the furthest north of the five sites on the northeastern tip of Ellesmere Island, is most isolated from continental sources (Hirdman et al., 2010).

The Zeppelin observatory is part of the European Supersites for Atmospheric Aerosol Research, where BC mass concentrations are also measured by an aethalometer and reported for seven wavelengths $(370,470,520,590,660$, 880 , and $950 \mathrm{~nm}$ ) (Eleftheriadis et al., 2009; data available at http://ebas.nilu.no/). We use the $520 \mathrm{~nm}$ data. Measurements at site Zeppelin, on the mountain Zeppelin on the island archipelago of Svalbard, were generally considered to represent the free-troposphere conditions (Eleftheriadis et al., 2009).

BC mass concentrations were also measured by an aethalometer at Summit (von Schneidemesser et al., 2009; data available at http://www.esrl.noaa.gov/gmd/aero/net/), on the center of the Greenland glacial ice sheet. The Summit site is at high elevation ( $3.2 \mathrm{~km}$ a.s.1.) and surrounded by flat and homogeneous terrain (Hirdman et al., 2010).

The uncertainty of filter-based absorption measurements of BC (PSAP and aethalometer) lies in empirical corrections of the overestimated absorption if light transmission is also affected by particulate light scattering (Bond et al., 1999). Accuracy of this correction is 20-30\% (Delene and Ogren, 2002; Weingartner et al., 2003; Virkkula et al., 2005). Additional uncertainty results from the empirical conversion from optical response to $\mathrm{BC}$ mass using an assumed MAC, which depends on the composition and morphology of the particles used in the calibration of the instrument and on the specific technique used to quantify the BC mass (Clarke et al., 1987; Slowik et al., 2007). The MAC of BC varies by up to a factor of $4\left(5-20 \mathrm{~m}^{2} \mathrm{~g}^{-1}\right)$ (Weingartner et al., 2003). We use $9.5 \mathrm{~m}^{2} \mathrm{~g}^{-1}$ for the station Barrow at wavelength $530 \mathrm{~nm}$ as recommended for the ARCTAS period (McNaughton et al., 2011; Wang et al., 2011). The MAC used at Alert (Sharma et al., 2013), Zeppelin (Eleftheriadis et al., 2009), and Summit 
(Hagler et al., 2007) are 19, 15.9, and $20 \mathrm{~m}^{2} \mathrm{~g}^{-1}$. The uncertainty of absorption enhancement by non-BC absorbers (organic carbon and mineral dust) is generally difficult to quantify unless the non-BC absorbers contribute more than $40 \%$ of absorption (Petzold et al., 2013).

\section{Model description and simulations}

\subsection{GEOS-Chem simulation of BC}

GEOS-Chem is a global three-dimensional (3-D) CTM driven with assimilated meteorology from the Goddard Earth Observing System (GEOS) of the NASA Global Modeling and Assimilation Office. The GEOS-5 meteorological data sets are used to drive model simulation at $2^{\circ}$ latitude $\times$ $2.5^{\circ}$ longitude resolution and 47 vertical layers from the surface to $0.01 \mathrm{hPa}$. The model averages over "polar caps" beyond $\pm 84^{\circ}$ to compensate for artificial polar singularities. Tracer advection is computed every $15 \mathrm{~min}$ with a flux-form semi-Lagrangian method (Lin and Rood, 1996). Tracer moist convection is computed using GEOS convective, entrainment, and detrainment mass fluxes as described by Allen et al. (1996a, b). Deep convection is parameterized using the relaxed Arakawa-Schubert scheme (Moorthi and Suarez, 1992; Arakawa and Schubert, 1974), and the shallow convection treatment follows Hack (1994). BC aerosols are emitted by incomplete fossil fuel and biofuel combustion and biomass burning. We use global $\mathrm{BC}$ emissions from Bond et al. (2007) with updated emissions in Asia from Zhang et al. (2009). Biomass-burning emissions are from the Global Fire Emissions Database version 3 (GFEDv3) (van der Werf et al., 2010) with updates for small fires in Randerson et al. (2012). It is assumed that $80 \%$ of the freshly emitted BC aerosols are hydrophobic (Park et al., 2003) and are converted to hydrophilic with an $e$-folding time of 1.15 days, which yields a good simulation of BC export efficiency in continental outflow (Park et al., 2005). Dry deposition in the model is computed using a resistance-in-series method (Wesely, 1989; Zhang et al., 2001), whereas it assumes a constant aerosol $v_{\mathrm{d}}$ of $0.03 \mathrm{~cm} \mathrm{~s}^{-1}$ over snow and ice (see Sect. 3.3). Wet deposition follows Liu et al. (2001), with updates as described in Wang et al. (2011).

\subsection{Gas-flaring emissions of $\mathrm{BC}$}

Gas flaring is the controlled burning of natural gas in petroleum producing areas, particularly in areas lacking gas transportation infrastructure (Elvidge et al., 2009, 2011). It is estimated that $3.5 \%$ of the world's natural gas is flared (Elvidge et al., 2016) and results in a large amount of greenhouse gas emissions (13662.6 $\mathrm{Gg}$ of $\mathrm{CO}_{2}$, Bradbury et al., 2015). Stohl et al. (2013) derived BC emissions from gas flares by multiplying gas-flaring volumes by emission factors. The flaring volumes were estimated using low-light imaging data acquired by the Defense Meteorological Satel- lite Program (DMSP) (Elvidge et al., 2011). The DMSP estimates of flared gas volume are based on a calibration developed with a pooled set of reported national gas-flaring volumes and data from individual flares. Derived using labbased, pilot-based, and field-based approaches, currently available $\mathrm{BC}$ emission factors vary by orders of magnitudes (0.0-6.4 $\mathrm{g} \mathrm{m}^{-3}$; Fawole et al., 2016). Stohl et al. (2013) derived $\mathrm{BC}$ emission factor $\left(1.6 \mathrm{~g} \mathrm{~m}^{-3}\right)$ based upon emission factors of particulate matter from flared gases. The resulting gas-flaring emissions $\left(228 \mathrm{Gg} \mathrm{yr}^{-1}\right)$ account for $\sim 5 \%$ of global anthropogenic emissions $\left(4.8 \mathrm{Tg} \mathrm{yr}^{-1}\right.$; Bond et al., $2007)$ and $\sim 3 \%$ of global total emissions $\left(8.5 \mathrm{Tg} \mathrm{yr}^{-1}\right.$; including anthropogenic emissions from Bond et al., 2007, and Zhang et al., 2009, and biomass-burning emissions from Randerson et al., 2012). However, the largest contributor Russia, contributing $\sim 30 \%$ to the global flaring volume, is located in the clean Arctic Circle. About $40 \%$ of BC emissions in the Arctic $\left(115 \mathrm{Gg} \mathrm{yr}^{-1}\right)$ are from gas flaring $\left(48 \mathrm{Gg} \mathrm{yr}^{-1}\right)$, shown in Fig. 1. It is estimated that flaring emissions contribute $42 \%$ to the annual mean $\mathrm{BC}_{\text {air }}$ at surface in the Arctic (Stohl et al., 2013). However, to our knowledge, no study so far has investigated the contribution of flaring emissions to $\mathrm{BC}_{\text {snow }}$ in the Arctic. Thus, we included flaring emissions from Stohl et al. (2013, data on flaring emissions are available at http://eclipse.nilu.no upon request) and investigated the contribution of flaring emissions to $\mathrm{BC}_{\text {snow }}$ and $\mathrm{BC}_{\mathrm{air}}$ in the Arctic in experiment $\mathrm{B}$ (Table 2).

\subsection{Dry deposition over snow and ice}

Nilsson and Rannik (2001) conducted eddy-covariance flux measurements of aerosol number dry deposition in the Arctic Ocean and found a mean $v_{\mathrm{d}}$ of $0.19 \mathrm{~cm} \mathrm{~s}^{-1}$ over open sea, $0.03 \mathrm{~cm} \mathrm{~s}^{-1}$ over ice floes and $0.03-0.09 \mathrm{~cm} \mathrm{~s}^{-1}$ over leads (Table 3). Following Nilsson and Rannik (2001), Fisher et al. (2011) imposed $v_{\mathrm{d}}=0.03 \mathrm{~cm} \mathrm{~s}^{-1}$ for aerosols over snow and ice. They found improved agreements of simulated sulfate with in situ observations in spring and winter in the Arctic. Wang et al. (2011), also imposing $v_{\mathrm{d}}=0.03 \mathrm{~cm} \mathrm{~s}^{-1}$ for aerosols over snow and ice, found better agreements for $\mathrm{BC}$ at the same stations as used by Fisher et al. (2011). They thus recommended a uniform $v_{\mathrm{d}}=0.03 \mathrm{~cm} \mathrm{~s}^{-1}$ for sulfate and $\mathrm{BC}$ over snow and ice. To capture the winter and spring haze, other studies also used relatively low $v_{\mathrm{d}}=0.01-$ $0.07 \mathrm{~cm} \mathrm{~s}^{-1}$ (Liu et al., 2011; Sharma et al., 2013). These low values, however, are likely too small for snow-covered land surface, where larger roughness lengths reduce the aerodynamic resistance thereby increasing $v_{\mathrm{d}}$ (Gallagher, 2002). The roughness length is $0.005 \mathrm{~m}$ for sea ice and $0.03-0.25 \mathrm{~m}$ for snow-covered land surface with grass and scattered obstacles (Wieringa, 1980). As a result, $v_{\mathrm{d}}$ is larger over a snowcovered land surface than over sea ice. Observed values over snow and ice are $0.01-2.4 \mathrm{~cm} \mathrm{~s}^{-1}$ for aerosol particles in general and $0.01-1.52 \mathrm{~cm} \mathrm{~s}^{-1}$ for BC in particular (Table 3). Again, this suggests that a uniform value of $v_{\mathrm{d}}=0.03 \mathrm{~cm} \mathrm{~s}^{-1}$ 
Table 2. GEOS-Chem simulations of BC in the Arctic.

\begin{tabular}{|c|c|c|c|c|c|}
\hline \multicolumn{2}{|l|}{ Experiments } & A & $\mathrm{B}$ & $\mathrm{C}$ & $\mathrm{D}$ \\
\hline \multirow{3}{*}{$\begin{array}{l}\text { Anthropogenic } \\
\text { emissions }\end{array}$} & Arctic & Bond et al. (2007) & \multicolumn{3}{|c|}{ Bond et al. (2007) and flaring emissions from Stohl et al. (2013) } \\
\hline & Asia & \multicolumn{4}{|c|}{ Zhang et al. (2009) } \\
\hline & Rest of world & \multicolumn{4}{|c|}{ Bond et al. (2007) } \\
\hline \multicolumn{2}{|l|}{ Biomass burning } & \multicolumn{4}{|c|}{ GFEDv3 (van der Werf et al., 2010), with updates from Randerson et al. (2012) } \\
\hline \multicolumn{2}{|l|}{ BC aging } & \multicolumn{4}{|c|}{$e$-folding time 1.15 days } \\
\hline \multirow[t]{3}{*}{ Deposition } & Dry & $\begin{array}{l}0.03 \mathrm{~cm} \mathrm{~s}^{-1} \text { over } \\
\text { and resistance-in-se } \\
\text { surfaces (Wang }\end{array}$ & $\begin{array}{l}\text { now/ice and } \\
\text { ies over other } \\
\text { al., 2011) }\end{array}$ & & $\begin{array}{l}\text { resistance-in-series over all surfaces } \\
\text { (Wesely, 1989; Zhang et al., 2001) }\end{array}$ \\
\hline & Wet & \multicolumn{4}{|c|}{ Liu et al. (2001) with updates from Wang et al. (2011) } \\
\hline & & \multicolumn{3}{|c|}{$\begin{array}{l}\text { riming: scavenging efficiency for hydrophilic } \\
\mathrm{BC} \text { is } 100 \% \text { in warm and mixed-phase clouds }\end{array}$} & $\begin{array}{l}\text { account for both riming and WBF in } \\
\text { mixed-phase clouds (Fukuta and Takahashi, 1999; } \\
\text { Verheggen et al., 2007; Cozic et al., 2007) }\end{array}$ \\
\hline
\end{tabular}

Table 3. Observed and simulated dry deposition velocity $\left(v_{\mathrm{d}}\right)$ using resistance-in-series method over snow and ice.

\begin{tabular}{|c|c|c|c|c|c|}
\hline Region & Sample & $\begin{array}{l}\text { Observed } v_{\mathrm{d}} \\
\qquad\left(\mathrm{cm} \mathrm{s}^{-1}\right)\end{array}$ & $\begin{array}{r}\text { Simulated } v_{\mathrm{d}} \\
\left(\mathrm{cm} \mathrm{s}^{-1}\right)\end{array}$ & References & Particle diameter \\
\hline Arctic Ocean & $\begin{array}{l}\text { open water leads, ice } \\
\text { ridges, snow and ice } \\
\text { surfaces }\end{array}$ & $0.027-0.068^{\mathrm{a}}$ & $0.006-0.070^{\mathrm{a}}$ & Held et al. (2011) & $<50 \mathrm{~nm}$ \\
\hline Arctic Ocean & open sea & $0.19^{b}$ & $0.013-0.22^{\mathrm{b}}$ & Nilsson and Rannik (2001) & $\begin{array}{l}\text { mostly ultrafine } \\
\text { and Aitken mode }\end{array}$ \\
\hline Arctic Ocean & $\begin{array}{l}\text { frozen, partly } \\
\text { snow-covered ice }\end{array}$ & $0.03^{\mathrm{b}}$ & & Nilsson and Rannik (2001) & \\
\hline Arctic Ocean & summer lead & $0.034^{\mathrm{b}}$ & & Nilsson and Rannik (2001) & \\
\hline Arctic Ocean & freeze-up lead & $0.091^{\mathrm{b}}$ & & Nilsson and Rannik (2001) & \\
\hline Greenland & snow (sulfate) & $0.023-0.062^{\mathrm{c}}$ & $0.007-0.16^{\mathrm{c}}$ & Bergin et al. (1995) & $<10 \mu \mathrm{m}$ \\
\hline Greenland & snow (sulfate) & $0.01-0.18^{\mathrm{d}}$ & $0.007-0.20^{\mathrm{d}}$ & Hillamo et al. (1993) & $0.6 \mu \mathrm{m}$ \\
\hline Greenland & snow & $0.2-0.7$ & & Hillamo et al. (1993) & $2 \mu \mathrm{m}$ \\
\hline Antarctic & snow grass & $0.02-0.1$ & & Wesely and Hicks (1979) & $0.05-1.0 \mu \mathrm{m}$ \\
\hline Antarctic & smooth snow surface & $0.33(0.08-1.89)$ & & Gronlund et al. (2002) & $14 \mathrm{~nm}$ \\
\hline Antarctic & $\begin{array}{l}\text { rocky surface inter- } \\
\text { rupted by snow }\end{array}$ & $0.8(0.2-2.4)$ & & Gronlund et al. (2002) & $42 \mathrm{~nm}$ \\
\hline Norway & snow & $0.06-0.38$ & & Dovland and Elliassen (1976) & \\
\hline Pennsylvania & $\begin{array}{l}\text { snow-covered farm } \\
\text { land in December }\end{array}$ & $0.034 \pm 0.014$ & & Duan et al. (1988) & $0.15-0.3 \mu \mathrm{m}$ \\
\hline Mt. Changbai & $\begin{array}{l}\text { snow-covered } \\
\text { mountain (BC) }\end{array}$ & $0.16-1.52^{\mathrm{e}}$ & $0.09-0.14^{\mathrm{e}}$ & Wang et al. (2014) & \\
\hline
\end{tabular}

\footnotetext{
a This range of measurements are medians of dry deposition velocities derived from aerosol number fluxes measured by an eddy-covariance system over different surface types (open water leads, ice ridges, snow, and ice surfaces) in the Arctic Ocean between $2-10^{\circ} \mathrm{W}$ longitude and $87-87.5^{\circ} \mathrm{N}$ latitude in late August 2008 (Held et al., 2011). The simulated dry deposition velocities are sampled at the same region during the same time period as observations for $\mathrm{BC}$ particles.

$\mathrm{b}$ Observations are medians of dry deposition velocities derived from aerosol number fluxes measured by an eddy-covariance system over different surface types in late July and early August in 1996 in the Arctic Ocean for ultra-fine and Aitken-mode aerosol particles (Nilsson and Rannik, 2001). Simulations are sampled in the same region during the same months as observations in 2008 for BC particles.

${ }^{c}$ Sulfate dry deposition velocities were derived based on particle mass using surrogate surfaces and impactor data at site Summit, Greenland in July 1993 (Bergin et al., 1995). Simulations are sampled at the same site during July 2008 for BC particles.

d Sulfate dry deposition velocities were derived based on particle mass from Cascade impactor at Dye 3 on the south-central Greenland Ice Sheet in March 1989 (Hillamo et al., 1993). Simulations are sampled at the same site during March 2008 for BC particles.

e The dry deposition velocities specific to BC particles were derived from measured surface enhancement of BC in snow between two snow events at Changbai Mountain in northern China in winter (December, January, and February) in 2009-2012 (Wang et al., 2014). Simulations are sampled at the same site during the same time period for BC particles.
} 
is problematic. We apply the resistance-in-series method to calculate $v_{\mathrm{d}}$ of $\mathrm{BC}$ over snow and ice, as a function of aerodynamic resistance, particle density and size, and surface types (experiment $\mathrm{C}$, Table 2).

We would like to note that most of these observations (Held et al., 2011; Nilsson and Rannik, 2001; Bergin et al., 1995) were from summertime Arctic (June-August) and clean regions (e.g., the Arctic Ocean and Greenland) far from anthropogenic pollution. In addition, most of the $v_{\mathrm{d}}$ measurements are for general aerosol particles. The only available dry deposition velocities specific to $\mathrm{BC}$ particles are derived from the strong surface enhancement of $\mathrm{BC}_{\text {snow }}$ between two snow events at Mt. Changbai $\left(42.5^{\circ} \mathrm{N}, 128.5^{\circ} \mathrm{E}\right.$; $0.74 \mathrm{~km}$ ) in northern China (Table 3). Wang et al. (2014) derived $v_{\mathrm{d}}=0.16-1.52 \mathrm{~cm} \mathrm{~s}^{-1}$. Despite uncertainties from sublimation (Wang et al., 2014), these measurements suggest that the low $v_{\mathrm{d}}$ used in previous studies (Fisher et al., 2011; Liu et al., 2011; Wang et al., 2011; Sharma et al., 2013) might underestimate the role of dry deposition during the snow season, particularly near source regions. Wang et al. (2014) concluded that dry deposition in the boundary layer may dominate over wet deposition (a factor of 5 larger) during the dry season in some regions, particularly near source regions with high $\mathrm{BC}_{\mathrm{air}}$. It is thus imperative to obtain measurements of $v_{\mathrm{d}}$ of $\mathrm{BC}$ in polluted regions in Russia and northern Europe in spring, when radiative forcing associated with a $\mathrm{BC}$ snowalbedo effect is at a maximum (Flanner, 2013).

\subsection{Wegener-Bergeron-Findeisen (WBF) process in mixed-phase clouds}

Most AeroCom models (Textor et al., 2006) parameterize rainout rate following Giorgi and Chameides (1986). The rainout ratio is proportional to the precipitation formation rate and mass mixing ratio of $\mathrm{BC}$ in a condensed phase in clouds, which is determined by the scavenging efficiency of $\mathrm{BC}\left(r_{\text {scav }}\right)$,

$r_{\text {scav }}=\frac{[\mathrm{BC}]_{\text {condensed }}}{[\mathrm{BC}]_{\text {interstitial }}+[\mathrm{BC}]_{\text {condensed }}}$,

where $r_{\text {scav }}$ is the scavenging efficiency and quantifies the partition of $\mathrm{BC}$ aerosols between condensed phase and the interstitial air; $[\mathrm{BC}]_{\text {condensed }}$ is the mass mixing ratio of $\mathrm{BC}$ in condensed phase, including water drops and ice crystals in clouds, and $[\mathrm{BC}]_{\text {interstitial }}$ is the mass mixing ratio of $\mathrm{BC}$ in the interstitial air.

The hygroscopicity and size of BC-containing particles are determining factors for $r_{\text {scav }}$ (Sellegri et al., 2003; Hallberg et al., 1992, 1995). Internal mixing with soluble inorganic species enhances the $r_{\text {scav }}$ for aged BC particles (Sellegri et al., 2003). For instance, $r_{\text {scav }}$ is $0.39 \pm 0.16$ for BCcontaining particles with a diameter smaller than $0.3 \mu \mathrm{m}$ and a small fraction (38\%) of soluble inorganic material. It increases to $0.97 \pm 0.02$ for particles with a diameter larger than $0.3 \mu \mathrm{m}$ and a larger fraction (57\%) of soluble inorganic material (Sellegri et al., 2003). In addition to particle properties, cloud microphysics and dynamics play a significant role in determining $r_{\text {scav }}$ of BC in mixed-phase clouds (Hitzenberger et al., 2000, 2001; Cozic et al., 2007; Hegg et al., 2011). Measured $r_{\text {scav }}$ of BC decreased from 0.60 in liquid only clouds to $0.05-0.10$ in mixed-phase clouds, a reduction of more than a factor of 5 (Cozic et al., 2007; Henning et al., 2004; Verheggen et al., 2007). Such reduction was attributed to the effect of the WBF process (Cozic et al., 2007). In mixed-phase clouds, ice crystals grow at the expense of water drops when the environmental vapor pressure is higher than the saturation vapor pressure of ice crystals but lower than the saturation vapor pressure of water droplets (Wegener, 1911; Bergeron, 1935; Findeisen, 1938). Therefore, BC-containing aerosol particles in water drops, which evaporate to dryness, are released back to the interstitial air and consequently $r_{\text {scav }}$ is reduced. Another process, riming (Hegg et al., 2011), in mixed-phase clouds has an opposite effect on BC scavenging. When ice particles fall and collect the water drops along the pathway, the snow particles show rimed structure and the scavenging efficiency remains the same. The riming rate is determined by the terminal velocity of snowflakes, ice crystals, and liquid water contents (LWC) in clouds (Fukuta and Takahashi, 1999).

Previously, only the hygroscopicity of BC-containing particles is considered in $\mathrm{BC} r_{\text {scav }}$ in models (Wang et al., 2011, and references therein). It is typically assumed that $100 \%$ of hydrophilic BC particles are readily incorporated into cloud drops and all hydrophobic BC particles remain in the interstitial air in warm and mixed-phase clouds. This treatment of mixed-phase clouds as liquid phase is likely to overestimate $r_{\text {scav }}$ in mixed-phase clouds. In models that include mixedphase clouds, assumptions still need to be made about $r_{\text {scav }}$. A uniform scavenging efficiency ( 0.4 or 0.06$)$ for all mixedphase clouds has been imposed (Stier et al., 2005; Bourgeois and Bey, 2011), while observations show that BC scavenging efficiency varies dramatically with temperature and ice mass fraction (Cozic et al., 2007; Henning et al., 2004; Verheggen et al., 2007).

In experiment D (Table 2), we discriminate WBF- vs. riming-dominated conditions and parameterize $\mathrm{BC}$ scavenging efficiency under the two conditions separately in mixedphase clouds ( $248 \mathrm{~K}<T<273 \mathrm{~K}$; Garrett et al., 2010). We assume that riming dominates when temperature is around $-10^{\circ} \mathrm{C}(261 \mathrm{~K}<T<265 \mathrm{~K})$ and LWC is above $1.0 \mathrm{~g} \mathrm{~m}^{-3}$, following Fukuta and Takahashi (1999). The WBF process dominates otherwise. Our parameterization of the effect of the WBF process on $\mathrm{BC}$ scavenging efficiency is based on the measurements at Mt. Jungfraujoch $\left(46.4^{\circ} \mathrm{N}, 8^{\circ} \mathrm{E} ; 3.85 \mathrm{~km}\right)$, an elevated mountainous site far from pollution sources and regularly engulfed in clouds (30\% of the time) (Cozic et al., 2007). We evaluated the effects of WBF on global BC distribution and tested the sensitivity of the simulation to the switch temperature from warm clouds to mixed-phase clouds and from mixed-phase clouds to ice clouds in a companion 
study (Qi et al., 2016). In this study, we focus on the effects of WBF on $\mathrm{BC}$ distribution in the Arctic.

\subsection{BC concentration in snow}

In snow models, such as SNICAR, the initial surface $\mathrm{BC}_{\text {snow }}$ is defined as the ratio of $\mathrm{BC}$ deposition to snow precipitation (Flanner et al., 2007). Here we approximate $\mathrm{BC}_{\text {snow }}$ using $\mathrm{BC}$ deposition flux and snow precipitation rate, following Kopacz et al. (2011), Wang et al. (2011), and He et al. (2014a):

$\left[\mathrm{BC}_{\text {snow }}\right]=\frac{F_{\mathrm{BC}, \text { dep }}}{F_{\text {snow }}}=\frac{F_{\text {wet_dep }}+F_{\text {dry_dep }}}{F_{\text {snow }}}$,

where $F_{\mathrm{BC} \text {,dep }}, F_{\text {wet_dep }}$, and $F_{\text {dry_dep }}$ are total, dry, and wet deposition flux of BC, and $F_{\text {snow }}$ is the snow precipitation. The top and bottom snow depth of each sample are provided in the observation data set (Doherty et al., 2010). We accumulate snow precipitation (GEOS-5) in the model from the collection date backward until the modeled snow depths, respectively, reach the observed top and bottom depths of the snow sample, then the two dates are stored. We use the average $\mathrm{BC}$ deposition fluxes and snow precipitation between the two dates to estimate the $\mathrm{BC}_{\text {snow }}$ for the sample. The rate of snow accumulation at the surface is estimated as snow precipitation flux $\left(\mathrm{kg} \mathrm{m}^{-2} \mathrm{~s}^{-1}\right)$ over snow density $\left(\mathrm{kg} \mathrm{m}^{-3}\right)$. The observed annual average snow density is $300 \mathrm{~kg} \mathrm{~m}^{-3}$ over the Arctic basin, increasing from $250 \mathrm{~kg} \mathrm{~m}^{-3}$ in September to $320 \mathrm{~kg} \mathrm{~m}^{-3}$ in May with little geographical variation across the Arctic (Warren et al., 1999; Forsström et al., 2013). We use the annual average snow density in the estimate.

The above estimate of $\mathrm{BC}_{\text {snow }}$ ignores many processes that may alter the $\mathrm{BC}$ snow concentrations, such as wind redistribution of surface snow, sublimation, and meltwater flushing (Doherty et al., 2010, 2013; Wang et al., 2014). Wind redistribution of surface snow is a subgrid-scale phenomenon. Except for turbulent-scale wind direction and strength, smallscale topography also plays an important role in surface snow distribution; this process is difficult to simulate in global models. Precipitation rate and relative humidity in much of the Arctic are low, so in some areas appreciable (up to 30$50 \%$ ) surface snow is lost to sublimation (Liston and Sturm, 2004). $\mathrm{BC}_{\text {snow }}$ at surface can thus be underestimated by our method. We filtered out snow samples collected during the melting season, so the meltwater flushing has little effect on our estimate.

To reduce the biases in comparison of model results and observations, we organize the observations as follows: (1) observations from March to May in 2007-2009 are used while those from June to August are excluded because our estimate of $\mathrm{BC}_{\text {snow }}$ does not resolve snow melting, (2) we exclude observations with obvious dust or local wood-burning contaminations as described in Doherty et al. (2010), and (3) we average the observations in the same model grid and snow layer and collected on the same day.
Table 2 summarizes various model simulations in the present study. Experiment A is the standard case. We include gas-flaring emissions in experiment B (Sect. 3.2). Contrasting experiments $\mathrm{B}$ and $\mathrm{A}$ thus offer insights to the contribution of gas-flaring emissions on BC in the Arctic. Experiment $\mathrm{C}$ includes the updated $v_{\mathrm{d}}$ (Sect. 3.3) as well as the gas-flaring emissions. The difference of experiment $\mathrm{B}$ and $\mathrm{C}$ denotes the effects of updated $v_{\mathrm{d}}$ to $\mathrm{BC}$ distribution. Experiment $\mathrm{D}$ includes temperature-based WBF parameterization (Sect. 3.4) as well as the gas flaring and $v_{\mathrm{d}}$ updates. The effects of WBF to BC in the Arctic are shown by the difference of experiment $\mathrm{C}$ and $\mathrm{D}$. Additional simulations are described where appropriate. In our discussion of the results of the model runs, we assume that there is little or no interaction between each of the updates; i.e., the order in which the processes have been included does not affect the overall results.

\section{The effects of gas flares, dry deposition, WBF, and precipitation}

We discuss the effects of gas-flaring emissions, dry deposition, WBF in mixed-phase clouds, and precipitation on $\mathrm{BC}$ distribution in the Arctic in this section. The probability density function of observed and GEOS-Chem simulated $\mathrm{BC}_{\text {snow }}$ in the Arctic is approximately lognormal (Fig. 2a). The arithmetic mean of observations is $17.4 \mathrm{ng} \mathrm{g}^{-1}$, larger than the geometric mean of $12.7 \mathrm{ng} \mathrm{g}^{-1}$ and the median of $11.8 \mathrm{ng} \mathrm{g}^{-1}$ (see the vertical lines in Fig. 2 and Table 1). The model reproduces the observed distribution, but underestimates $\mathrm{BC}_{\text {snow }}$ by $40 \%$ (experiment $\left.\mathrm{A}\right)$. By including flaring emissions (Sect. 4.1), updating $v_{\mathrm{d}}$ (Sect. 4.2), and including WBF in mixed-phase clouds (Sect. 4.3), the discrepancy is reduced to $-10 \%$. Gas-flaring emissions lower the discrepancy from -40 to $-20 \%$ (experiment $\mathrm{B}$ ). The updated $v_{\mathrm{d}}$ (experiment $\mathrm{C}$ ) makes insignificant changes to $\mathrm{BC}_{\text {snow }}$ in the Arctic. WBF (experiment D) further reduces the discrepancy from -20 to $-10 \%$. The resulting $\mathrm{BC}_{\text {snow }}$ in the eight subregions agree with observations within a factor of 2 . This discrepancy is acceptable for global models because it has been suggested that the error due to different spatial sampling of global models $(\sim 200 \mathrm{~km})$ and point observations was up to $160 \%$ (Schutgens et al., 2016). In addition, $\mathrm{BC}_{\text {air }}$ at the surface and in the free troposphere is sensitive to the above three processes in the Arctic, particularly during winter and spring (see Sect. 4.1-4.3).

\subsection{Gas-flaring emissions}

Gas-flaring emissions increase total $\mathrm{BC}$ emissions by $67 \%$ (from 0.068 to $\left.0.115 \mathrm{Tg} \mathrm{yr}^{-1}\right)$ in the Arctic Circle $\left(60^{\circ} \mathrm{N}\right.$ and higher latitudes), resulting in a $19 \%$ increase of the total $\mathrm{BC}$ deposition (from 0.32 to $0.38 \mathrm{Tg} \mathrm{yr}^{-1}$ ). Flaring emissions increase $\mathrm{BC}_{\text {snow }}$ (by $0.1-8.5 \mathrm{ng} \mathrm{g}^{-1}$ ) in the eight Arctic 

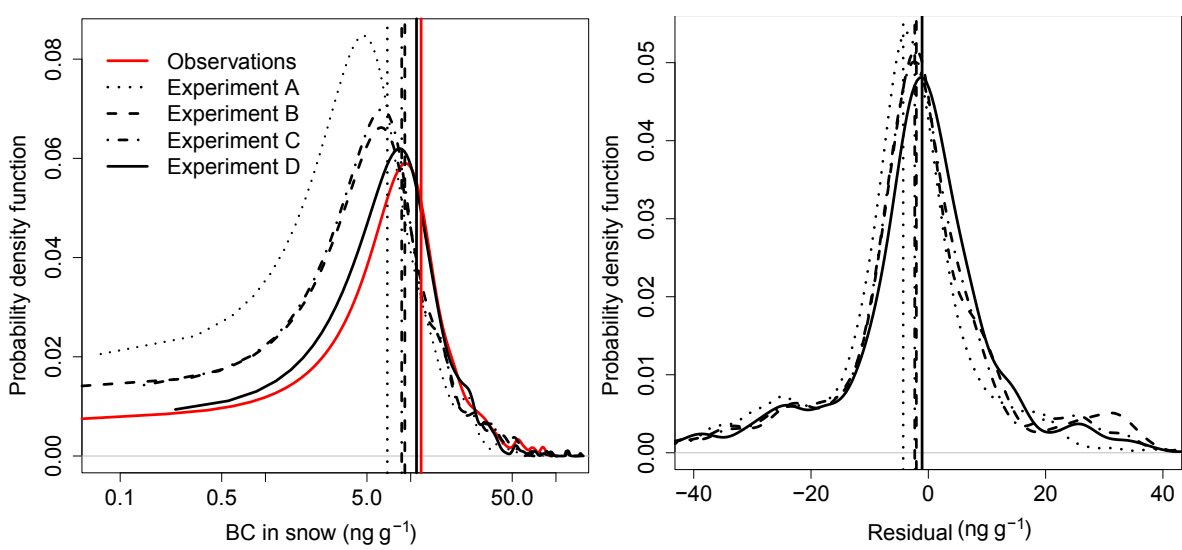

Figure 2. Probability density function of observed (solid red) and GEOS-Chem simulated (black curves: dotted - experiment A; dashed experiment B; dash dotted - experiment C; solid - experiment D; see Table 2 and text for details) $\mathrm{BC}$ concentration in snow (ng $\mathrm{g}^{-1}$ ) in the Arctic (left panel), medians (vertical lines, left panel), residual errors (model-observation, right panel), and mean residual errors (vertical lines, right panel).

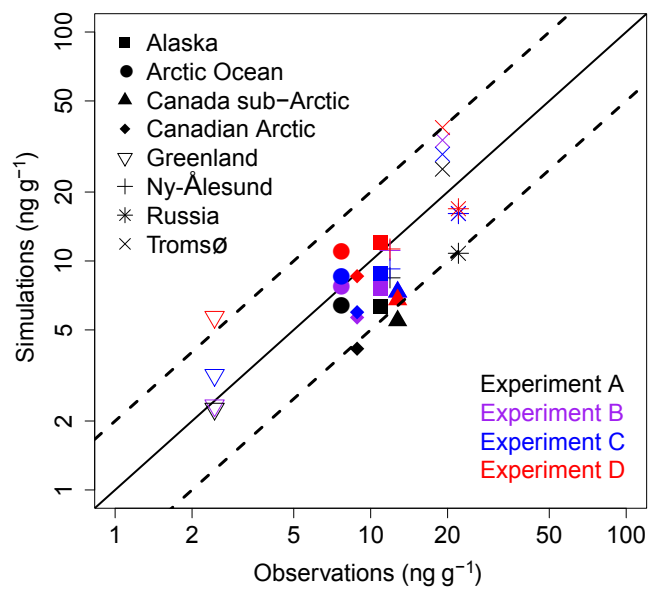

Figure 3. Observed and GEOS-Chem simulated median BC concentration in snow $\left(\mathrm{ng} \mathrm{g}^{-1}\right)$ in the eight sub-regions in the Arctic (see Fig. 1). Solid line is 1:1 ratio line and dashed lines are 1:2 (or 2:1).

sub-regions. The higher $\mathrm{BC}_{\text {snow }}$ leads to a significant reduction in the negative biases (by 20-100\%), except in the Arctic Ocean and in Troms $\varnothing$, where $\mathrm{BC}_{\text {snow }}$ is already overestimated without flaring emissions (Fig. 3). $\mathrm{BC}_{\text {snow }}$ in Greenland is not affected by gas-flaring emissions. The reason is 2fold: first, snow samples in Greenland are far from the flares in western Russia, and second, the vertical transport of BC from surface to the upper troposphere is suppressed by the stable atmosphere in the Arctic (Stohl, 2006), resulting in a negligible effect of flaring emissions to $\mathrm{BC}_{\text {snow }}$ over Greenland (above $1.5 \mathrm{~km}$ ).

The largest enhancement of $\mathrm{BC}_{\text {snow }}$ from flaring emissions is in the western side of the extreme north of Russia within the Arctic Circle (by $5.0 \mathrm{ng} \mathrm{g}^{-1}$ on average, or, $50 \%$ ), which reduces model discrepancy substantially across Russia (from -50 to $-30 \%$ ). However, simulated $\mathrm{BC}_{\text {snow }}$ is now too high (by a factor of 2) near the flares (observed value $\sim 19.3 \mathrm{ng} \mathrm{g}^{-1}$ ). The overestimate is likely because of excessively large flaring emission estimates. Yet $\mathrm{BC}_{\text {snow }}$ is too low (by a factor of 2) in far fields (observed value $\sim 30.7 \mathrm{ng} \mathrm{g}^{-1}$ ), despite a large increase (by $50 \%$, from 10.5 to $15.5 \mathrm{ng} \mathrm{g}^{-1}$ ) as a result of flaring emissions.

Flaring emissions are assumed to be proportional to flared gas volumes and emission factors. Errors in estimates of flared volumes in Russia are small (within $\pm 5 \%$, Elvidge et al., 2009). Estimates of emission factors, on the other hand, are known to have several orders of magnitude uncertainties (Schwarz et al., 2015; Weyant et al., 2016). Given limited observations of BC emission factors from actual flares, Stohl et al. (2013) derived BC emission factor based upon emission factors of particulate matter from flared gases. They used a $\mathrm{BC}$ emission factor of $1.6 \mathrm{~g} \mathrm{~m}^{-3}$, which is more than a factor of 3 higher than that $\left(0.5 \mathrm{~g} \mathrm{~m}^{-3}\right)$ from a lab experiment on fuel mixtures typical in the oil and gas industry (McEwen and Johnson, 2012). Recent field measurements have suggested an even lower emission factor $\left(0.13 \pm 0.36 \mathrm{~g} \mathrm{~m}^{-3}\right)$ from $\sim 30$ individual flares in North Dakota, with an upper bound of $0.57 \mathrm{~g} \mathrm{~m}^{-3}$ (Schwarz et al., 2015; Weyant et al., 2016). These studies found that average $\mathrm{BC}$ emission factors for individual flares varied by 2 orders of magnitude and, furthermore, two flares from the same flare stack that were resampled on different days showed different $\mathrm{BC}$ emission factors (Weyant et al., 2016). They also pointed out that emission factors are not correlated with ambient temperature, pressure, humidity, flared gas volumes, or gas composition. It is thus imperative that extensive measurements of $\mathrm{BC}$ emission factors be made in the flare regions.

Yet another source of uncertainty is flare stack height, which is not accounted for in current flaring emission estimates. Typical stack heights vary from 15 to $250 \mathrm{~m}$, some- 
times above the nighttime boundary layer height of 150 $300 \mathrm{~m}$ in the Arctic (Di Liberto et al., 2012). The stack height affects the ventilation, dispersion, deposition, and long-range transport of the emissions. For example, local deposition of $\mathrm{BC}$ may be suppressed and downwind long-range transport enhanced when the stacks emitted BC in the free troposphere (Chen et al., 2009). The lack of proper treatment of flare stack height in the model may partially explain the aforementioned discrepancies of modeled $\mathrm{BC}_{\text {snow }}$ (biased high in western Russian and low in eastern Russia). Another factor for the underestimate of $\mathrm{BC}_{\text {snow }}$ in eastern Russia is likely local sources, such as domestic wood burning in nearby villages and fishing camps, diesel trucks on the highway, and coal burning in a power plant, which are unaccounted for in the emission inventory (Doherty et al., 2010, Fig. 1). Although we filter out samples with strong local contamination, it is conceivable that local emissions still add to the background $\mathrm{BC}_{\text {snow }}$ in eastern Russia.

Jiao et al. (2014) have shown that most AeroCom models underestimated $\mathrm{BC}_{\text {snow }}$ in Russia and pointed to the flaring emissions as a likely cause. Our model results show that even with flaring emissions, which are likely on the high side, $\mathrm{BC}_{\text {snow }}$ is still too low (by $50 \%$ ) in eastern Russia. Therefore, there are likely other factors such as the lack of local emissions in eastern Russia, weak dry deposition fluxes (Sect. 4.2), and excessively low rates of sublimation of surface snow, which contribute to the large model discrepancy in $\mathrm{BC}_{\text {snow }}$.

Figure 4 shows observed and GEOS-Chem simulated daily $\mathrm{BC}_{\mathrm{air}}$ from January to March at Zeppelin, a site that is closest to the gas flares in the western side of the extreme north of Russia. The inclusion of flaring emissions captures some of the large spikes in the observed $\mathrm{BC}_{\mathrm{air}}$, such as those from late February to March in 2008 and in January 2009. Stohl et al. (2013) found that flaring emissions captured observed large spikes at Zeppelin during a transport event in February 2010 with a high BC / CO ratio, a signature of gas-flaring emissions (CAPP, 2007). The inclusion of flaring emissions results in enhanced $\mathrm{BC}_{\mathrm{air}}$, for instance, in February 2007 and in January 2008, which are not seen in the observations. This is largely from the lack of temporal variation of flaring emissions (Weyant et al., 2016). The temporal variation is, however, difficult to characterize based on the current knowledge of flaring emissions on the western side of the extreme north of Russia (Stohl et al., 2013). Flaring emissions also increase $\mathrm{BC}_{\text {air }}$ during the snow season (September to April) (by 16$19 \mathrm{ng} \mathrm{m}^{-3}$ ) at Barrow and Alert, resulting in substantial reductions of discrepancies (from -47 to $-15 \%$ at Barrow and -67 to $-46 \%$ at Alert) (Fig. 5). The effect of flaring emissions at Denali in the low Arctic is negligible, because the site is outside of the cold Arctic front (around $65-70^{\circ} \mathrm{N}$ in Alaska) (Barrie, 1986; Ladd and Gajewski, 2010), which is a strong barrier for the meridional transport of BC (Stohl, 2006). $\mathrm{BC}_{\mathrm{air}}$ at Summit (3.22 km a.s.1.), which is mostly in the free troposphere, is not affected by flaring emissions ei-
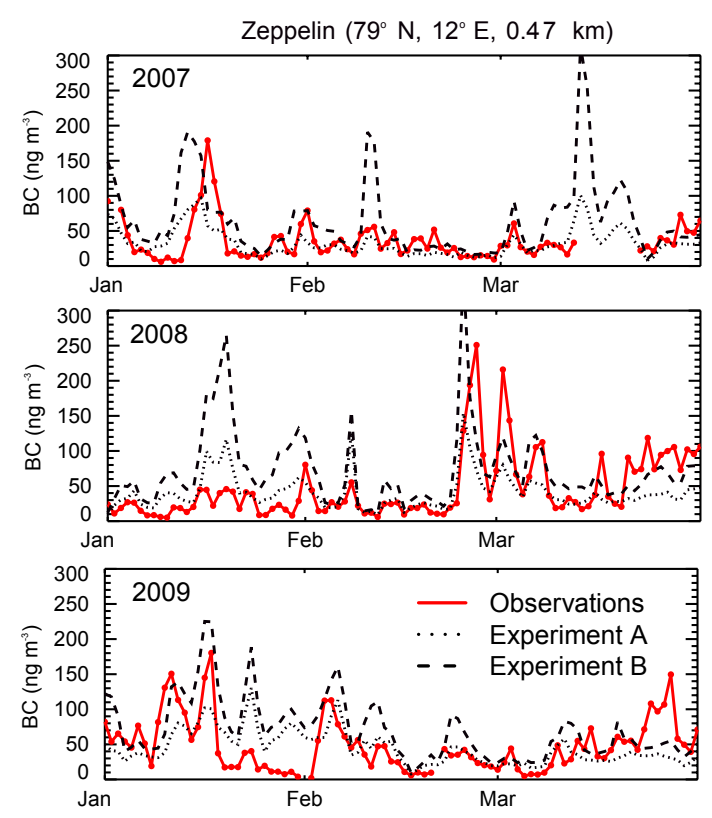

Figure 4. Observed (red solid) and GEOS-Chem simulated (dotted - Exp. A, dashed - Exp. B; see Table 2 and text for details) daily BC concentrations in air $\left(\mathrm{ng} \mathrm{m}^{-3}\right)$ at Zeppelin from January to March in 2007-2009.

ther. This is because the vertical transport of BC is suppressed by the stable atmosphere during the snow season in the Arctic (Stohl, 2006).

\subsection{Dry deposition velocity}

It is known that $v_{\mathrm{d}}$ of aerosol particles over snow and ice surfaces strongly depends on particle size, surface types and meteorological conditions and varies by orders of magnitude (Table 3). We estimate $v_{\mathrm{d}}$ of $\mathrm{BC}$ particles as a function of particle properties, aerodynamic resistance, and surface types (Sect. 3.3). The results over the Arctic Ocean and Greenland are shown in Table 3, generally within the observed range. At Mt. Changbai, the model result of BC $v_{\mathrm{d}}(0.09-$ $0.14 \mathrm{~cm} \mathrm{~s}^{-1}$ ) is an order of magnitude lower than that derived by Wang et al. (2014) $\left(0.16-1.52 \mathrm{~cm} \mathrm{~s}^{-1}\right)$. The resulting dry deposition fluxes are lower than observations by a factor of 5 . We attribute the large discrepancies to two factors. First, the point measurements were at a mountainous site with complex terrain and micro-meteorological conditions. Neither can be resolved in a global model (He et al., 2014a). Second, the values reported by Wang et al. (2014) were estimated from relative enhancements of surface $\mathrm{BC}_{\text {snow }}$ between two snow events. These estimates are known to have large uncertainties (a factor of 2) from the measured sublimation fluxes and the assumption of snow density (Wang et al., 2014).

Compared to the results of uniform $v_{\mathrm{d}}$ of $0.03 \mathrm{~cm} \mathrm{~s}^{-1}$ over snow and ice, the updated $v_{\mathrm{d}}$ leads to larger dry deposition fluxes, a larger fraction of dry over total deposition, and rel- 

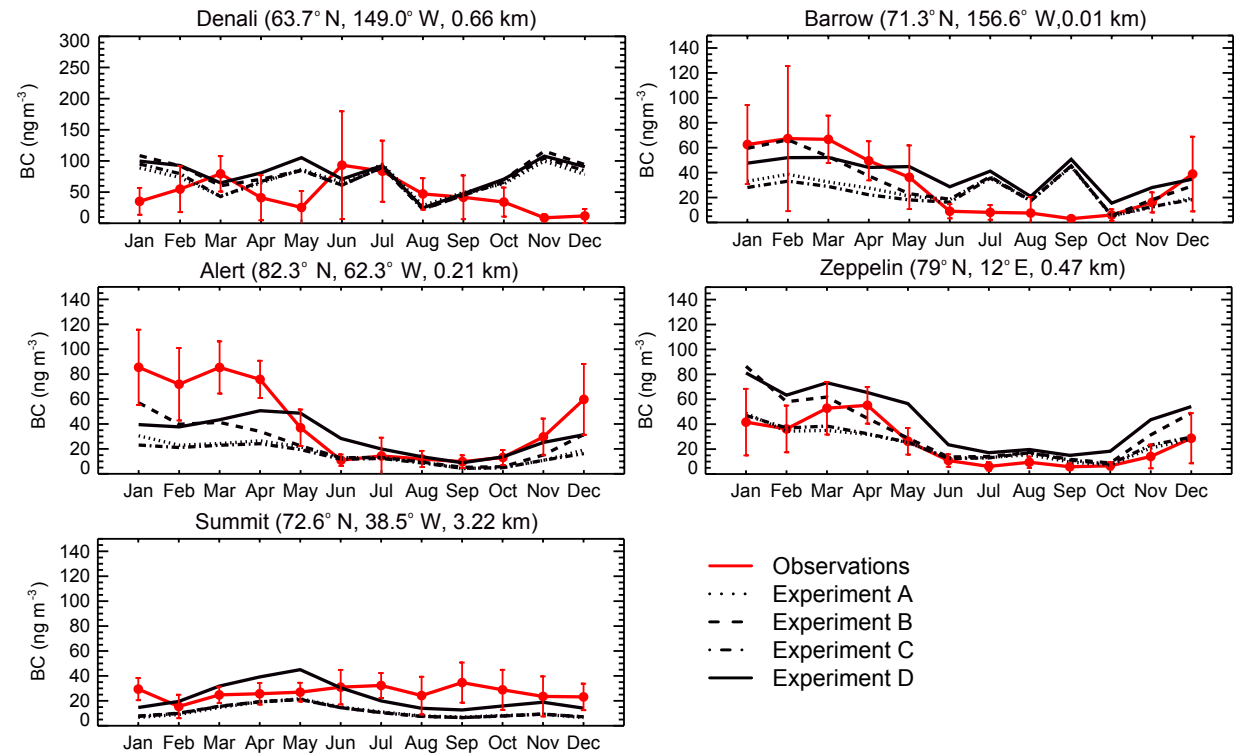

Figure 5. Observed (red solid) and GEOS-Chem simulated (black curves: dotted - Exp. A, dashed - Exp. B, dash dotted - Exp. C, solid Exp. D; see Table 2 and text for details) BC concentrations in air $\left(\mathrm{ng} \mathrm{m}^{-3}\right)$ at Denali, Barrow, Alert, Zeppelin, and Summit, averaged for 2007-2009. Also shown are standard deviations of observations (error bars).

atively unchanged total deposition fluxes. Simulated mean $\mathrm{BC} v_{\mathrm{d}}$ in the eight Arctic sub-regions (Fig. 1) are 0.03$0.14 \mathrm{~cm} \mathrm{~s}^{-1}$, which is considerably larger that the uniform value of $0.03 \mathrm{~cm} \mathrm{~s}^{-1}$ over snow and ice (Table 5). Correspondingly, the $v_{\mathrm{d}}$ are $19-195 \%$ larger in most sub-regions, with the largest increase in Greenland (by 195\%) and over Russia (by 87\%) (Table 5). We find that BC dry deposition flux is more sensitive to $v_{\mathrm{d}}$ in source regions (e.g., Russia) than in remote regions, reflecting the high $\mathrm{BC}_{\text {air }}$ in the former. A comparable increase in $v_{\mathrm{d}}$ of $\mathrm{BC}$ (from 0.03 to $0.08 \mathrm{~cm} \mathrm{~s}^{-1}$ ) in Russia and Alaska results in vastly different increases in BC dry deposition flux (87\% in Russia vs. $30 \%$ in Alaska). As expected, larger dry deposition flux depletes $\mathrm{BC}_{\text {air }}$ thereby reducing wet deposition flux but offsets the reduction in wet deposition. As a result, both total deposition flux and $\mathrm{BC}_{\text {snow }}$ remain relatively unchanged $(<5 \%)$ in the eight sub-regions, except in Ny-Ålesund and Troms $\emptyset$. In these latter two regions, the total deposition fluxes are 10$15 \%$ smaller. The lower deposition fluxes reflect efficient removal of BC aerosols over source regions. BC in Ny-Ålesund and Troms $\varnothing$ are primarily from Europe and Russia, transported isentropically in the cold season (Stohl, 2006; Eleftheriadis et al., 2009). Rapid dry deposition in these source regions results in enhanced boundary layer removal hence lower BC loadings in air and a reduced boundary layer outflow (Liu et al., 2011).

The change in the fraction of dry to total deposition has important implications for $\mathrm{BC}$ radiative forcing in the Arctic. The fraction increases from $19 \%$ (7-33\%) to $26 \%$ (14$41 \%$ ), by $14-73 \%$, with the largest increase in Russia (from 23 to $40 \%$ ) where $\mathrm{BC}$ deposition flux and $\mathrm{BC}_{\text {snow }}$ are the largest in the Arctic (Tables 4 and 5). Typically, BC particles removed by dry deposition are externally mixed with snow particles, while those removed by wet deposition are internally mixed with snow particles (Flanner et al., 2009, 2012). Internal mixing of $\mathrm{BC}$ with snow/ice particles increases the absorption cross section of $\mathrm{BC} /$ snow composites by about a factor of 2 (Flanner et al., 2012). The enhanced absorption further increases the snow-albedo radiative forcing (He et al., 2014b). It is thus conceivable that the larger dry deposition fraction will lead to less internally mixed $\mathrm{BC} /$ snow composite and lower snow-albedo radiative forcing. This effect is critical before the melting season, because melting might quickly eliminate the differences in the mode of BC deposition. Other post-depositional processes include wind-driven drifting and sublimation (Doherty et al., 2013). The former does not change the fraction of external and internal mixing of $\mathrm{BC}$ with snow. The latter might expose $\mathrm{BC}$ particles in the internally mixed $\mathrm{BC} /$ snow composite and reduce the fraction of internally mixed $\mathrm{BC} /$ snow composite. Yet this process occurs slowly in a relatively long time.

Unlike $\mathrm{BC}_{\text {snow }}, \mathrm{BC}_{\text {air }}$ is a strong function of $v_{\mathrm{d}}$, particularly during the snow season. With updated $v_{\mathrm{d}}$, model results fail to capture the seasonal cycle of $\mathrm{BC}_{\text {air }}$ with dramatic decreases during the snow season (by 20-23 $\mathrm{ng} \mathrm{m}^{-3}, 27-68 \%$ ) at Barrow, Alert, and Zeppelin (Fig. 5). The decreases at Barrow and Alert are a direct result of larger dry deposition in the boundary layer because of substantially larger $v_{\mathrm{d}}$ $\left(0.07 \mathrm{~cm} \mathrm{~s}^{-1}\right.$, Table 5). At Zeppelin (in Ny-Ålesund), where $v_{\mathrm{d}}$ is only marginally higher $(17 \%)$, the large reduction of $\mathrm{BC}_{\text {air }}(\sim 40 \%)$ is largely attributed to the suppressed transport from proximate source regions in Europe and Russia. 
Table 4. Observed and GEOS-Chem simulated BC concentration in snow in the Arctic (ng $\mathrm{g}^{-1}$; see Fig. 1).

\begin{tabular}{|c|c|c|c|c|c|c|c|c|c|c|c|}
\hline & & & Arctic & Alaska & $\begin{array}{l}\text { Arctic } \\
\text { Ocean }\end{array}$ & $\begin{array}{r}\text { Canadian sub- } \\
\text { Arctic }\end{array}$ & $\begin{array}{r}\text { Canadian } \\
\text { Arctic }\end{array}$ & Greenland & Ny-Ålesund & Russia & Troms $\varnothing$ \\
\hline Sample size & & & 334 & 3 & 23 & 34 & 86 & 8 & 39 & 118 & 23 \\
\hline \multirow{5}{*}{$\begin{array}{l}\text { Arithmetic } \\
\text { mean }\end{array}$} & \multirow{5}{*}{$\begin{array}{l}\text { Observed } \\
\text { experiment }\end{array}$} & & 19.8 & 12.4 & 8.0 & 14.8 & 8.8 & 3.2 & 13.7 & 28.3 & 19.3 \\
\hline & & A & $10.9\left(0.6^{*}\right)$ & $6.0(0.5)$ & $8.5(1.1)$ & $7.7(0.5)$ & $5.7(0.7)$ & $3.6(1.1)$ & $10.9(0.8)$ & $12.3(0.4)$ & $35.6(1.8)$ \\
\hline & & B & $15.0(0.8)$ & $7.7(0.6)$ & $10.8(1.4)$ & $9.3(0.6)$ & $6.7(0.8)$ & $3.6(1.1)$ & $14.9(1.1)$ & $19.6(0.7)$ & $41.8(2.2)$ \\
\hline & & $\mathrm{C}$ & $15.1(0.8)$ & $8.0(0.6)$ & $10.3(1.3)$ & $9.1(0.6)$ & $7.0(0.8)$ & $4.3(1.3)$ & $12.8(0.9)$ & $20.7(0.7)$ & $38.4(2.0)$ \\
\hline & & $\mathrm{D}$ & $16.0(0.8)$ & $12.2(1.0)$ & $12.4(1.6)$ & $8.5(0.6)$ & $8.8(1.0)$ & $5.1(1.6)$ & $14.9(1.1)$ & $19.4(0.7)$ & $45.8(2.4)$ \\
\hline \multirow{5}{*}{$\begin{array}{l}\text { Geometric } \\
\text { Mean }\end{array}$} & Observed & & 12.9 & 11.4 & 6.8 & 13.2 & 8.2 & 2.7 & 11.2 & 21.2 & 18.8 \\
\hline & experiment & A & $7.6(0.6)$ & $5.9(0.5)$ & $7.3(1.1)$ & $5.9(0.5)$ & $4.9(0.6)$ & $2.3(0.9)$ & $8.4(0.8)$ & $9.3(0.4)$ & $28.3(1.5)$ \\
\hline & & B & $10.4(0.8)$ & $7.6(0.7)$ & $9.6(1.4)$ & $7.6(0.6)$ & $6.1(0.7)$ & $2.4(0.9)$ & $11.4(1.0)$ & $14.3(0.7)$ & $35.1(1.9)$ \\
\hline & & $\mathrm{C}$ & $10.1(0.8)$ & $7.9(0.7)$ & $9.3(1.4)$ & $7.3(0.6)$ & $6.3(0.8)$ & $2.8(1.0)$ & $9.7(0.9)$ & $13.9(0.7)$ & $31.6(1.7)$ \\
\hline & & $\mathrm{D}$ & $11.5(0.9)$ & $11.6(1.0)$ & $11.6(1.7)$ & $7.6(0.6)$ & $8.1(1.0)$ & $3.8(1.4)$ & $11.9(1.0)$ & $14.2(0.7)$ & $37.2(2.0)$ \\
\hline \multirow[t]{5}{*}{ Median } & Observed & & 11.8 & 11.0 & 7.6 & 12.8 & 8.9 & 2.5 & 11.9 & 22.1 & 19.1 \\
\hline & & A & $6.9(0.6)$ & $6.3(0.6)$ & $6.4(0.8)$ & $5.5(0.4)$ & $4.1(0.5)$ & $2.3(0.9)$ & $8.4(0.7)$ & $10.8(0.5)$ & $25.2(1.3)$ \\
\hline & & B & $9.5(0.8)$ & $7.6(0.7)$ & $7.7(1.0)$ & $7.3(0.6)$ & $5.7(0.6)$ & $2.3(0.9)$ & $11.1(0.9)$ & $16.1(0.7)$ & $33.7(1.8)$ \\
\hline & & $\mathrm{C}$ & $8.7(0.7)$ & $7.8(0.7)$ & $8.5(1.1)$ & $7.3(0.6)$ & $6.0(0.7)$ & $3.2(1.3)$ & $9.2(0.8)$ & $16.1(0.7)$ & $29.2(1.5)$ \\
\hline & & $\mathrm{D}$ & $11.0(0.9)$ & $12.1(1.1)$ & $10.9(1.4)$ & $6.8(0.5)$ & $8.6(1.0)$ & $5.7(2.3)$ & $11.3(1.0)$ & $16.9(0.8)$ & $38.2(2.0)$ \\
\hline
\end{tabular}

* Ratio of model to observation.

Table 5. GEOS-Chem simulated BC dry deposition velocity $\left(\mathrm{cm} \mathrm{s}^{-1}\right)$, dry deposition flux (ng $\mathrm{m}^{-2}$ day $^{-1}$ ), and fraction of dry to total deposition (\%) in the Arctic.

\begin{tabular}{|c|c|c|c|c|c|c|c|c|c|c|c|}
\hline \multirow[t]{2}{*}{ Region } & \multicolumn{2}{|c|}{$\begin{array}{c}\text { Dry deposition } \\
\text { velocity }\left(\mathrm{cm} \mathrm{s}^{-1}\right)\end{array}$} & \multicolumn{3}{|c|}{$\begin{array}{l}\text { Dry deposition flux } \\
\left(\mathrm{ng} \mathrm{m}^{-2} \text { day }^{-1}\right)\end{array}$} & \multicolumn{3}{|c|}{$\begin{array}{l}\text { Total deposition flux } \\
\quad\left(\mathrm{ng} \mathrm{m}^{-2} \mathrm{day}^{-1}\right)\end{array}$} & \multicolumn{3}{|c|}{$\begin{array}{l}\text { Dry deposition fraction } \\
(\%)\end{array}$} \\
\hline & Exp. B & $\begin{array}{r}\text { Exps. C } \\
\text { and D }\end{array}$ & Exp. B & Exp. C & Exp. D & Exp. B & Exp. C & Exp. D & Exp. B & Exp. C & Exp. D \\
\hline Alaska & 0.03 & 0.08 & 787 & 1018 & 1906 & 2393 & 2469 & 3665 & 33 & 41 & 52 \\
\hline Arctic Ocean & 0.03 & 0.07 & 662 & 789 & 1520 & 4480 & 4227 & 4733 & 15 & 19 & 32 \\
\hline Canadian sub-Arctic & 0.04 & 0.08 & 841 & 1192 & 2297 & 5669 & 5596 & 5013 & 15 & 21 & 46 \\
\hline Canadian Arctic & 0.03 & 0.07 & 661 & 988 & 1948 & 3194 & 3289 & 3343 & 20 & 30 & 58 \\
\hline Greenland & 0.03 & 0.10 & 262 & 772 & 1804 & 3887 & 4245 & 4481 & 7 & 18 & 40 \\
\hline Ny-Ålesund & 0.12 & 0.14 & 2654 & 2322 & 4861 & 19528 & 16713 & 19536 & 14 & 14 & 25 \\
\hline Russia & 0.03 & 0.08 & 3092 & 5782 & 7288 & 13647 & 14465 & 12336 & 23 & 40 & 59 \\
\hline Tromsø & 0.12 & 0.13 & 5826 & 5110 & 9339 & 46382 & 42085 & 49598 & 13 & 12 & 19 \\
\hline
\end{tabular}

This dramatic decrease of $\mathrm{BC}_{\text {air }}$ in winter with larger $v_{\mathrm{d}}$ and the lack of winter and spring Arctic haze is one of the major reasons for using low $v_{\mathrm{d}}$ in previous studies (Wang et al., 2011; Sharma et al., 2013; Liu et al., 2011). However, this does not justify the use of a low $v_{\mathrm{d}}$ over snow and ice. First, observations have shown very large variations of $v_{\mathrm{d}}$ (Table 3), which suggest that a uniform representation might involve large uncertainties. Second, observations of $v_{\mathrm{d}}$ over snow and ice show very large values in certain regions, which is still underestimated by the resistance-in-series method. Third, besides dry deposition in boundary layer, $\mathrm{BC}_{\mathrm{air}}$ is affected by many other factors, such as emissions, transport, and wet deposition (Sect. 4.3).

\subsection{WBF in mixed-phase clouds}

Our model results show that WBF increases $\mathrm{BC}_{\text {snow }}$ by 20 $80 \%$ in the eight Arctic sub-regions, except Canadian subArctic, and increases $\mathrm{BC}_{\text {air }}$ during the snow season by $25-$ $70 \%$ (Figs. 2 and 7). Inclusion of a parameterization of the WBF process in the model suppresses the scavenging of BC in mixed-phase clouds and consequently enhances poleward transport. We validate the simulation of WBF and the associated effects on global $\mathrm{BC}$ distribution in a companion study (Qi et al., 2016).

The parameterized $\mathrm{WBF}$ process not only increases $\mathrm{BC}_{\text {snow }}$ in the model Arctic but also changes the partition of dry and wet deposition of $\mathrm{BC}_{\text {snow. }}$. Intuitively, WBF slows down wet scavenging, thus allowing for more $\mathrm{BC}$ particles available for dry deposition. Our model results show that the 
fraction of dry to total deposition increases from $26 \%$ (12$41 \%)$ to $35 \%(19-59 \%)$ on average in the eight Arctic subregions, thereby lowering the absorption of solar radiation due to less internally mixed BC-snow composite (Sect. 4.2). In Alaska, Canadian Arctic, and Russia, BC removed by dry deposition increases to more than $50 \%$. However, averaged globally, this fraction increases only slightly (from 19 to $20 \%$ ), indicating that the fraction in the Arctic is more sensitive to the WBF parameterization in our model.

The scavenging efficiency of $\mathrm{BC}$, heretofore defined as the fraction of $\mathrm{BC}$ incorporated in cloud water drops or ice crystals in mixed-phase clouds, is strongly affected by the WBF parameterization and as a result varies temporally and spatially in response to varying temperature (Sect. 3.3). Thus, improved treatment of mixed-phase cloud processes, such as WBF and riming, is essential to improve the simulation of spatial and temporal distribution of BC. BC in Alaska and the Canadian Arctic are most sensitive to the WBF effect in the Arctic in our model. WBF increases $\mathrm{BC}_{\text {snow }}$ by $55 \%$ in Alaska and $43 \%$ in the Canadian Arctic and reduces the model discrepancies to within $10 \%$ (Table 4 and Fig. 3). $\mathrm{BC}_{\text {air }}$ at Barrow in Alaska and at Alert in Canadian Arctic are higher by $20-30 \mathrm{ng} \mathrm{m}^{-3}$ in winter, reducing the model discrepancies significantly (from -54 to $-18 \%$ at Barrow and from -72 to $-46 \%$ at Alert) and enhancing the seasonal variation (Fig. 5). Similar improvements are also seen at Summit in Greenland, where $\mathrm{BC}_{\text {air }}$ increases by $12 \mathrm{ng} \mathrm{m}^{-3}$ and the model discrepancy lowers significantly (from -48 to $3 \%$ ). This modeling result is consistent with recent observations, which showed that a high riming rate was rare $(12 \%)$ in the North American sector of the Arctic and that WBF dominated in-cloud scavenging in mixed-phase clouds (Fan et al., 2011).

At Zeppelin where snow samples show rimed structures (Hegg et al., 2011), model discrepancy of $\mathrm{BC}_{\text {air }}$ increases to 63 from $-10 \%$ with the WBF effect included. Model results do not capture the magnitude of $\mathrm{BC}_{\mathrm{air}}$ in winter at Barrow, Alert, and Zeppelin (Fig. 5). $\mathrm{BC}_{\text {air }}$ is well simulated at Zeppelin but underestimated at Barrow and Alert in experiment $\mathrm{A} . \mathrm{BC}_{\mathrm{air}}$ is well simulated at Barrow and Alert but overestimated at Zeppelin in experiment D (Fig. 5) - similar results were shown in Sharma et al. (2013). Such apparent discrepancy can be partly attributed to the fact that models do not properly distinguish WBF-dominated in-cloud scavenging at Barrow (Fan et al., 2011) and riming-dominated scavenging at Zeppelin (Hegg et al., 2011). Here we separate WBF- and riming-dominated conditions based on temperature and LWC (Sect. 3.3; Fukuta and Takahashi, 1999) in experiment D. However, model results still fail to capture the difference among the three sites. There are a number of reasons. First, LWC from GEOS-5 biased high compared to CloudSat observations (Barahona et al., 2014). In addition, the spatial distribution of LWC from GEOS-5 also has a large discrepancy (Li et al., 2012; Barahona et al., 2014). Second, this separation is based on a laboratory experiment, while conditions in the real atmosphere are much more complex. Therefore, more field measurements are required to better separate the two conditions and better parameterize BC scavenging efficiency.

Our model results show that the WBF parameterization exaggerates the positive bias of $\mathrm{BC}_{\mathrm{air}}$ in summer and delays the transition from the late-spring haze to the clean summer boundary layer (experiment D). Previous studies found that the dominant process controlling low summertime aerosol at Barrow is the onset of local wet scavenging by warmer clouds (Garrett et al., 2010, 2011). The WBF parameterization has the effect of suppressing scavenging in mixed-phase clouds and thus slows down the onset of strong scavenging by warmer clouds during the transition from winter to summer. However, the strong scavenging of warm drizzling clouds in late spring and summer boundary layer (Browse et al., 2012), which enhances the winter-summer transition, is not considered in the present study. At high latitudes in summer, low stratocumulus cloud decks in the boundary and lower troposphere produce frequent drizzle $(90 \%$ of the time) and remove aerosol effectively (Browse et al., 2012).

\subsection{Precipitation}

We compute $\mathrm{BC}_{\text {snow }}$ as the ratio of $\mathrm{BC}$ deposition flux to precipitation rate (Sect. 3.5). It has been pointed out that this estimate is very sensitive to uncertainties in precipitation (He et al., 2014a). Climatological precipitation across the Arctic is $14.3 \mathrm{~g} \mathrm{~cm}^{-2} \mathrm{yr}^{-1}$ for 1965-1989 (Overland and Turet, 1994) and is $16.3 \mathrm{~g} \mathrm{~cm}^{-2} \mathrm{yr}^{-1}$ for 1971-1991 (Serreze et al., 1995) as constrained from an observed hydrologic budget (Warren et al., 1999). The annual precipitation, averaged for 20072009 , is $15.5 \mathrm{~g} \mathrm{~cm}^{-2} \mathrm{yr}^{-1}$ in GEOS-5, within the range of the observations. There are considerable uncertainties, spatially and temporally, in precipitation in the Arctic (Warren et al., 1999; Serreze and Hurst, 2000). Figure 6 compares monthly precipitation from the Global Precipitation Climatology Project (GPCP; Huffman et al., 2001), NOAA Climate Prediction Center Merged Analysis of Precipitation (CMAP; Xie and Arkin, 1997), and GEOS-5. The discrepancies can be as large as a factor of 10 and the seasonal cycles are largely out of phase between the three data sets. Specifically, GPCP precipitation is much stronger than CMAP, particularly during summer. GEOS-5 precipitation is within the range of GPCP and CMAP data. The exception is Greenland, NyÅlesund, and Troms $\varnothing$, where GEOS-5 precipitation is substantially (a factor of 2-10) larger than GPCP and CMAP data during the snow season. Snow precipitation in the Arctic is difficult to constrain for two reasons. First, accurate measurements of snowfall in the Arctic have proven nearly impossible, because snow gauges strongly under-catch snowfall (by 55-75\%) depending on the gauge type and wind condition (Liston and Sturm, 2004). Second, a more fundamental problem is that the sparse observational network in the Arctic is vastly inadequate to accurately estimate the monthly mean 

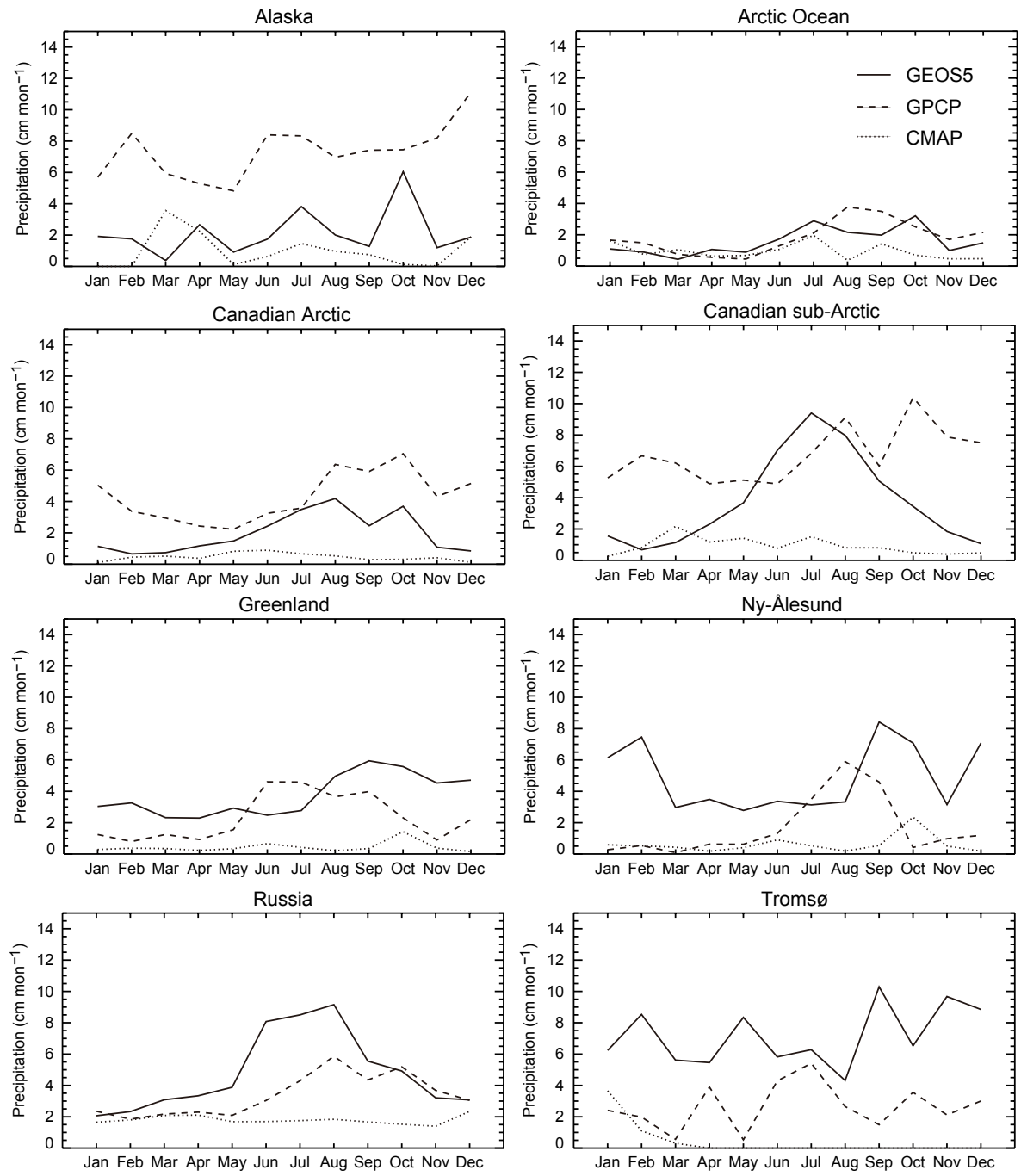

Figure 6. Monthly precipitation (cm month ${ }^{-1}$ ) averaged over sub-regions in the Arctic for 2006-2008 (Fig. 1). Data are from the Goddard Earth Observing System Model version 5 data assimilation system (GEOS-5 DAS), Global Precipitation Climatology Project (GPCP), and NOAA Climate Prediction Center Merged Analysis of Precipitation (CMAP).

precipitation (Serreze and Hurst, 2000) - 10-40 stations are required in $2.5^{\circ}$ grid cells (WCRP, 1997).

To probe the sensitivity of $\mathrm{BC}$ deposition and $\mathrm{BC}_{\text {snow }}$ to precipitation, we conduct two additional model simulations, where we halve and double the precipitation rate in the Arctic, with other processes configured as in experiment $\mathrm{D}$. We find that, in GEOS-5, during the snow season, nearly all precipitation is in the form of snow in the Arctic. Halving precipitation leads to increases in $\mathrm{BC}_{\text {snow }}$ by $15-136 \%$, with the largest enhancements in Greenland (136\%) and Ny-Ålesund (92\%) (Fig. 7). With precipitation halved, it takes a longer accumulation time for a given snow depth, which results in larger dry deposition (up to $153 \%$ increases). Therefore, the ratio of $\mathrm{BC}$ dry deposition to snow precipitation increases as well. On the other hand, the ratio of BC wet deposition to snow precipitation, determined mainly by in-cloud scaveng- ing of $\mathrm{BC}$, remains largely unchanged. Overall, $\mathrm{BC}_{\text {snow }}$ increases with halved precipitation. Doubled precipitation has the opposite effect. Indeed, $\mathrm{BC}_{\text {snow }}$ decreases by $14-43 \%$ in the eight Arctic sub-regions. In addition, dry deposition decreases by $35-62 \%$ and the fraction of dry to total deposition decreases by $23-43 \%$. Although $\mathrm{BC}_{\text {snow }}$ as computed here is sensitive to precipitation, the resulting medians of $\mathrm{BC}_{\text {snow }}$ in the eight sub-regions are in agreement with observations within a factor of 2, except over Greenland (a factor of 5 too high) and Troms $\varnothing$ (a factor of 3 too high). Further analysis of the results at Greenland and Troms $\varnothing$ is in Sect. 4.5. The strong sensitivity of $\mathrm{BC}_{\text {snow }}$ calls for a better constraining of precipitation in the Arctic.

In contrast, annual $\mathrm{BC}$ loading and deposition are much less sensitive to precipitation (Table 6). Halving Arctic precipitation increases annual $\mathrm{BC}$ loading by $12 \%$ and de- 
Table 6. Model simulations of $\mathrm{BC}$ in the Arctic $\left(60\right.$ to $\left.90^{\circ} \mathrm{N}\right)$.

\begin{tabular}{|c|c|c|c|c|c|c|c|c|c|}
\hline Model & & $\begin{array}{r}\text { Global } \\
\text { emission }^{b} \\
\left(\operatorname{Tg~yr}^{-1}\right)\end{array}$ & $\begin{array}{r}\text { Arctic } \\
\text { emission }^{b} \\
\left(\mathrm{Tg} \mathrm{yr}^{-1}\right)\end{array}$ & $\begin{array}{r}\text { Arctic } \\
\text { deposition }^{\mathrm{b}} \\
\left(\mathrm{Tg} \mathrm{yr}^{-1}\right)\end{array}$ & $\begin{array}{r}\text { Arctic } \\
\text { loading } \\
\left(\mathrm{mg} \mathrm{m}^{-2}\right)\end{array}$ & $\begin{array}{r}\text { Arctic } \\
\text { lifetime }^{\mathrm{d}} \\
(\text { day })\end{array}$ & $\begin{array}{r}\mathrm{BC}_{\text {snow }} \\
\text { bias }^{\mathrm{e}} \\
\left(\mathrm{ng} \mathrm{g}^{-1}\right)\end{array}$ & $\begin{array}{r}\mathrm{BC}_{\text {snow }} \\
r^{\mathrm{e}}\end{array}$ & $\begin{array}{l}\text { Year of } \\
\text { deposition } \\
\text { field }^{b}\end{array}$ \\
\hline \multirow{6}{*}{$\begin{array}{l}\text { GEOS- } \\
\text { Chem }^{\text {a }}\end{array}$} & Experiment A & 8.3 & 0.068 & 0.32 & 0.24 & 9.9 & -5.3 & $0.15^{\mathrm{h}}$ & $2006-2009$ \\
\hline & Experiment B & 8.5 & 0.115 & 0.38 & 0.27 & 9.5 & -2.5 & $0.24^{\mathrm{h}}$ & 2006-2009 \\
\hline & Experiment $\mathrm{C}$ & 8.5 & 0.115 & 0.37 & 0.25 & 9.2 & -2.9 & $0.23^{\mathrm{h}}$ & $2006-2009$ \\
\hline & Experiment D & 8.5 & 0.115 & 0.37 & 0.43 & 16.3 & -0.8 & $0.21^{\mathrm{h}}$ & 2006-2009 \\
\hline & Exp. D_50\% precip. & 8.5 & 0.115 & 0.31 & 0.48 & 20.7 & +5.8 & $0.22^{\mathrm{h}}$ & 2006-2009 \\
\hline & Exp. D_200\% precip. & 8.5 & 0.115 & 0.40 & 0.37 & 12.6 & -4.4 & $0.20^{\mathrm{h}}$ & 2006-2009 \\
\hline \multicolumn{2}{|c|}{ AeroCom Phase $\mathrm{I}^{\mathrm{f}}$} & 7.8 & 0.069 & $0.11-0.22$ & - & - & $-13.2-(-0.5)^{\mathrm{g}}$ & $0.11-0.28$ & - \\
\hline AeroCom & HADGEM2 & 6.6 & 0.063 & 0.34 & 0.34 & 22.6 & +18.7 & $0.18^{\mathrm{h}}$ & $2006-2008$ \\
\hline \multirow[t]{8}{*}{ Phase II } & GOCART & 10.3 & 0.058 & 0.29 & 0.14 & 16.0 & +7.3 & 0.04 & 2006 \\
\hline & OsloCTM2 & 7.8 & 0.068 & 0.28 & 0.07 & 6.9 & +21.4 & $0.10^{\mathrm{h}}$ & 2006 \\
\hline & GISS-modelE & 7.6 & 0.077 & 0.22 & 0.16 & 11.6 & +7.8 & $0.21^{\mathrm{h}}$ & 2004-2008 \\
\hline & SPRINTARS & 8.1 & 0.037 & 0.22 & 0.08 & 6.9 & +5.3 & 0.06 & 2006 \\
\hline & CAM4-Oslo & 10.6 & 0.056 & 0.21 & 0.20 & 22.7 & -0.2 & $0.12^{\mathrm{h}}$ & Present-day \\
\hline & GMI & 7.8 & 0.059 & 0.20 & 0.08 & 7.7 & +1.9 & $0.10^{\mathrm{h}}$ & 2006 \\
\hline & IMPACT & 10.6 & 0.039 & 0.16 & 0.05 & - & +3.8 & $0.18^{\mathrm{h}}$ & Present-day \\
\hline & CAM5.1 & 7.8 & 0.056 & 0.13 & 0.02 & - & -13.0 & $0.23^{\mathrm{h}}$ & 2006 \\
\hline
\end{tabular}

a This study.

b AeroCom model results are from Jiao et al. (2014).

c AeroCom models simulated Arctic Burdens are for year 2000 using only anthropogenic emissions from Samset et al. (2013).

${ }^{\mathrm{d}}$ Lifetime is approximated by dividing the annual Arctic BC column burden by the annual Arctic deposition flux.

e BC snow concentrations were calculated using CLM4 and CICE4 models with monthly deposition field from AeroCom models (Jiao et al., 2014).

f Paticipating models are DIR, GISS, LOA, LSCE, MATCH, MPI-HAM, TM5, UIO-CTM, UIO-GCM,UIO-GCM-V2, ULAQ, UMI, CAM-Oslo (Jiao et al., 2014).

$\mathrm{g}$ This range is for the AeroCom Phase I models except for ULAQ, which is the only one to produce a positive bias of $+10.7 \mathrm{ng} \mathrm{g}^{-1}$.

$\mathrm{h}$ The regression is significant at $\alpha=0.05$.

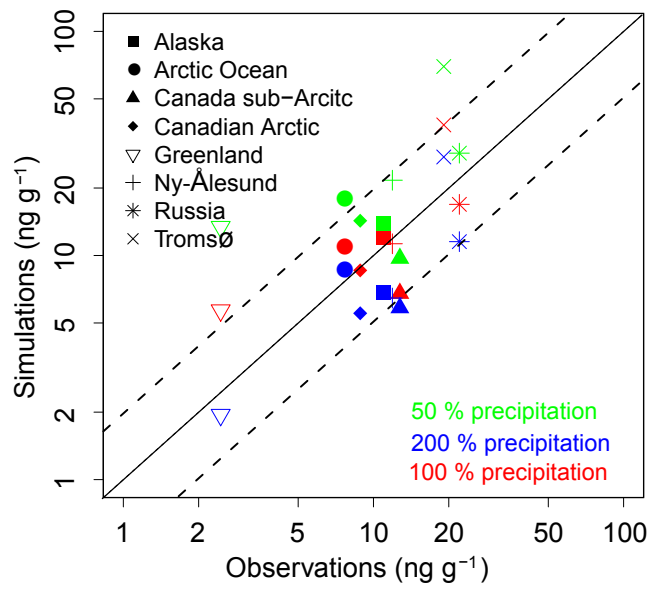

Figure 7. Same as Fig. 3, but for Exp. D with standard precipitation (red symbols), $50 \%$ precipitation (green symbols), and $200 \%$ precipitation (blue symbols). See text for details.

creases annual $\mathrm{BC}$ deposition by $16 \%$ in the Arctic. This is because less precipitation removes fewer $\mathrm{BC}$ particles. $\mathrm{BC}$ lifetime in the Arctic, as determined by the $\mathrm{BC}$ loading and deposition, increases by $27 \%$. When precipitation is doubled, annual BC loading decreases by $14 \%$, while BC deposition increases by $8 \%$, resulting in a $23 \%$ reduction of $\mathrm{BC}$ lifetime in the Arctic.
$\mathrm{BC}_{\mathrm{air}}$ is more sensitive to precipitation at Barrow, Alert, and Zeppelin than at Denali and Summit (Fig. 8). When precipitation is halved, annual $\mathrm{BC}_{\text {air }}$ increases by $20-70 \%$ at Alert, by $10-40 \%$ at Barrow and Zeppelin, and by $1-20 \%$ at Denali and Summit. When precipitation is doubled, annual $\mathrm{BC}_{\mathrm{air}}$ decreases by $20-50 \%$ at Alert, by $10-40 \%$ at Barrow and Zeppelin, and by $2-20 \%$ at Denali and Summit. Additionally, $\mathrm{BC}_{\mathrm{air}}$ is more sensitive to precipitation in summer than in winter. This is because the summer clean boundary layer in the Arctic is controlled by strong local scavenging (Garrett et al., 2010, 2011; Browse et al., 2012).

\subsection{BC in snow in Greenland, Tromsø, and Canadian sub-Arctic}

$\mathrm{BC}_{\text {snow }}$ is associated with much larger uncertainties over short (hence shallower snow depth) than longer (hence larger snow depth) time periods. Because snow samples over Greenland were collected at the very surface $(\sim 0 \mathrm{~cm})$, the computed $\mathrm{BC}_{\text {snow }}$ thus represents $\mathrm{BC}$ deposition only through the duration of a day for direct comparisons. The short time duration thus largely explains the larger uncertainties in the estimated $\mathrm{BC}_{\text {snow }}$. In Troms $\varnothing$, observed $\mathrm{BC}_{\text {snow }}$ were considerably lower $\left(19.1 \mathrm{ng} \mathrm{g}^{-1}\right)$ from samples collected over a clean mountain plateau upwind of the town Troms $\varnothing$ (Doherty et al., 2010) and much higher (53.3 $\mathrm{ng} \mathrm{g}^{-1}$ ) 

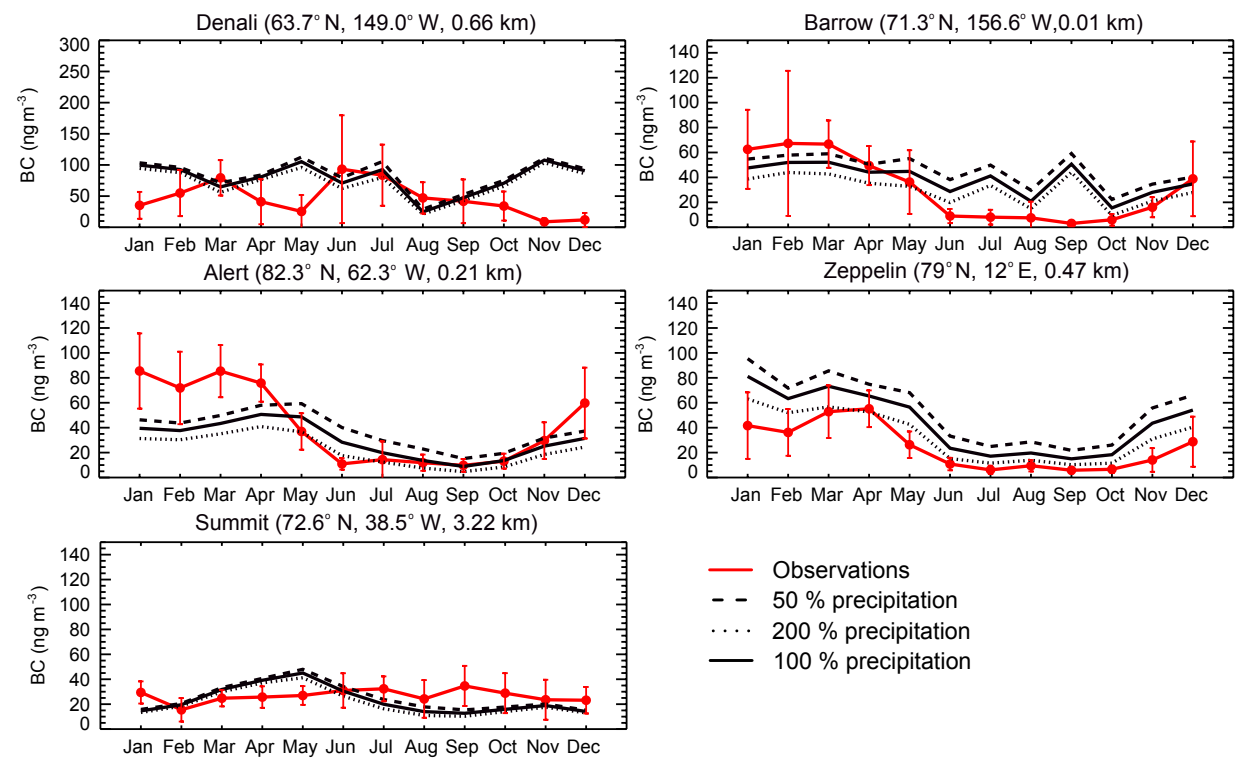

Figure 8. Same as Fig. 5, but for Exp. D with standard precipitation (solid black), $50 \%$ precipitation (dashed black), and $200 \%$ precipitation (dotted black). See text for details.

from samples collected in the town (Forsström et al., 2013). We use the former for comparisons. Thus, the factor of 2 overestimate of $\mathrm{BC}_{\text {snow }}$ in this region is because GEOSChem does not resolve subgrid variability.

In the Canadian sub-Arctic, $\mathrm{BC}_{\text {snow }}$ is underestimated by $50 \%$ with all the improvements discussed above (experiment $\mathrm{D}$ ). This large low bias is mainly from the low $\mathrm{BC}_{\text {snow }}$ in the subsurface samples $\left(1-20 \mathrm{~cm}, 11.7 \mathrm{ng} \mathrm{g}^{-1}, \sim 60 \%\right.$ of all samples) accumulated through the snow season. $\mathrm{BC}_{\text {snow }}$ in this region of the model increases by $33 \%$ from flaring emissions and by $43 \%$ from halving precipitation. Yet the resulting $\mathrm{BC}_{\text {snow }}$ is still $25 \%$ lower than observations $\left(12.8 \mathrm{ng} \mathrm{g}^{-1}\right)$. However, GEOS-5 precipitation is at the lower end among the three precipitation data sets (Fig. 6). The large discrepancy in $\mathrm{BC}_{\text {snow }}$ warrants further studies.

\section{Discussions}

Global BC emissions in this study are within the range of previous studies, but emissions in the Arctic $\left(0.115 \mathrm{Tg} \mathrm{yr}^{-1}\right)$ exceed the higher end of those used in previous studies (0.037$0.077 \mathrm{Tg} \mathrm{yr}^{-1}$, Table 6). The large Arctic emissions in this study result from gas flares, which have been missing in most previous estimates. It has been suggested that gas flares are a dominant $\mathrm{BC}$ source in the Arctic - it is $42 \%$ of the total $\mathrm{BC}$ emissions in the Arctic, but a rather small fraction (3\%) of the global BC emissions (Stohl et al., 2013). Although this estimate is probably biased high because of the large emission factor (Sect. 4.1), including gas-flaring emissions in modeling Arctic BC appears to be justified from our results.
BC deposition in the Arctic $\left(0.38 \mathrm{Tg} \mathrm{yr}^{-1}\right)$ exceeds the higher end of those used in previous studies (0.13$0.34 \mathrm{Tg} \mathrm{yr}^{-1}$ ), with flaring emissions included (Table 6). Our model results suggest that annual BC deposition in the Arctic is more sensitive to the $\mathrm{BC}$ emissions and precipitation rate in the region than to $v_{\mathrm{d}}$ and WBF. Flaring emissions increases BC deposition flux in the Arctic by $19 \%$ in the model. In the model, doubling precipitation in the Arctic increases BC deposition by $8 \%$; halving precipitation decreases BC deposition by $18 \%$. Total modeled $\mathrm{BC}$ emissions in the Arctic are a factor of 2-5 lower than total modeled $\mathrm{BC}$ deposition, suggesting that a large fraction of $\mathrm{BC}$ deposited in the Arctic is from long-range transport.

Simulation of $\mathrm{BC}_{\text {snow }}$ in this study is much better than most of the AeroCom models in the perspective of mean model bias across the Arctic (experiment D in this study: $-0.8 \mathrm{ng} \mathrm{g}^{-1}$; AeroCom models: $-13.2-+21.4 \mathrm{ng} \mathrm{g}^{-1}$; Table 6) and the biases for the eight sub-regions (experiment $D$ in this study: a factor of 2; AeroCom estimates: a factor of 56; Jiao et al., 2014). In addition, the correlation coefficient of modeled and simulated $\mathrm{BC}_{\text {snow }}$ in this study $(0.21)$ is located at the higher end of previous AeroCom estimates (0.12$0.24)$. We find that flaring emissions improve the agreement of $\mathrm{BC}_{\text {snow }}$ with observations significantly, with a $50 \%$ reduction to the negative bias of modeled $\mathrm{BC}_{\text {snow }}$ across the Arctic and a substantially stronger correlation ( 0.15 to 0.24$)$ between simulated and observed $\mathrm{BC}_{\text {snow }}$ in the region (Table 6). WBF further reduces the average bias across the Arctic by $70 \%$. Overall, modeled $\mathrm{BC}_{\text {snow }}$ is poorly correlated with observations ( $r=0.15$ to 0.24 ) for all AeroCom models and GEOS-Chem. This disagreement is probably resulted 
from a common problem in the Arctic, which is the poorly constrained meteorological fields including precipitation in the Arctic due to the scarcity of observations in the region (Sect. 4.4). Our model results show that doubling precipitation introduces a much larger positive bias, similar to the magnitude of the overall effects of flaring emissions and the WBF effect; halving precipitation produces a similarly large negative bias (Sect. 4.4).

Modeled atmospheric BC loading in the Arctic in this study exceeds the high end of the previous AeroCom estimates $\left(0.02-0.34 \mathrm{mg} \mathrm{m}^{-2}\right)$ by including the WBF effect (Table 6). We find that $\mathrm{BC}$ scavenging efficiency plays a more important role in determining $\mathrm{BC}$ loading in the Arctic than emissions, $v_{\mathrm{d}}$, and precipitation. BC loading in this region increases by $13 \%$ from flaring emissions, which represents $\mathrm{a} \sim 70 \%$ enhancement to previous emission estimates, and by $7 \%$ from updated dry deposition velocity, which is, in some cases, a factor of 2-3 larger than the default value of $0.03 \mathrm{~cm} \mathrm{~s}^{-1}$. In addition, Arctic BC loading in the atmosphere increases by $12 \%$ when precipitation is halved and decreases by $14 \%$ when precipitation is doubled. Modeled WBF reduces BC scavenging efficiency in mixed-phase clouds by $20-80 \%$ and increases annual BC loading by $70 \%$ in the Arctic. This large sensitivity of BC loading in the Arctic to treatments of BC scavenging efficiency in mixed-phase clouds and in ice clouds is also shown by previous studies. For example, Bourgeois and Bey (2011) reduced the scavenging efficiency in mixed-phase clouds from $0.10-0.75$ to a uniform value of 0.06 in the ECHAM5-HAMMOZ model (Pozzoli et al., 2008) and found that the resulting BC $_{\text {air }}$ in the Arctic increased by up to a factor of 10 and were in improved agreement with aircraft observations. In addition, their model results of $\mathrm{BC}$ burden in the Arctic were 5 times higher. We note here that a scavenging efficiency of 0.06 is on the low end of observed values in mixed-phase clouds (Cozic et al., 2007; Verheggen et al., 2007), which leads to a considerably larger WBF effect. Liu et al. (2011) found that lowering BC scavenging efficiency in ice clouds (from 0.2 to 0.01 ) in the AM3 model (Anderson et al., 2004) dramatically enhanced BC transport to the Arctic (nearly 10 times higher) and improved model comparison with aircraft observations. Browse et al. (2012) suppressed the scavenging of soluble BC in ice clouds in the GLOMAP model (Mann et al., 2010) and found that the resulting $\mathrm{BC}_{\mathrm{air}}$ in the Arctic were 6 times higher. Better characterization of scavenging efficiency in all could types globally is thus critical for accurately reproducing BC distribution and the associated climatic effects in the Arctic.

\section{Summary and conclusions}

This study sought to understand the capability of GEOSChem in simulating BC distribution both in air and in snow in the Arctic and the controlling factors. We evaluated the model simulation against $\mathrm{BC}_{\text {snow }}$ measurements across the
Arctic and in situ measurements of surface $\mathrm{BC}_{\mathrm{air}}$ at Denali in the low Arctic, Barrow, Alert, and Zeppelin in the high Arctic, and Summit in the free troposphere. We also examined the role of gas-flaring emissions, $v_{\mathrm{d}}$, the WBF effect, and precipitation on $\mathrm{BC}$ distribution in the Arctic. We first included $\mathrm{BC}$ emissions from a missing source in the current emission inventories: natural gas flares. We then used the resistancein-series method to estimate $v_{\mathrm{d}}$ of $\mathrm{BC}$ over snow and ice to replace the uniform constant $v_{\mathrm{d}}$ of $0.03 \mathrm{~cm} \mathrm{~s}^{-1}$ over snow and ice. We also parameterized the effects of the WBF process on $\mathrm{BC}$ scavenging efficiency in mixed-phase clouds. WBF was stronger at lower temperature.

With all these changes, the discrepancy of $\mathrm{BC}_{\text {snow }}$ across the whole Arctic decreased substantially (from -40 to $-10 \%)$. In the eight sub-regions, the simulated $\mathrm{BC}_{\text {snow }}$ agreed with observations within a factor of 2 . We also found that including flaring emissions significantly improves the simulation of $\mathrm{BC}_{\text {snow }}$ with a strong reduction of discrepancy (from -40 to $-20 \%$ ) and an increase of correlation coefficient with observations (from 0.15 to 0.24 ). WBF further reduced the discrepancy of $\mathrm{BC}_{\text {snow }}$ to within $-10 \%$, with the largest improvement in the North American section in the Arctic. Simulation of $\mathrm{BC}_{\text {snow }}$ with the abovementioned improvements was among the best AeroCom models evaluated by Jiao et al. (2014). The resulting $\mathrm{BC}_{\mathrm{air}}$ agreed with observations within a factor of 2, also among the best simulations in Eckhardt et al. (2015).

In addition to these physical processes, we also tested the sensitivity of $\mathrm{BC}_{\text {snow }}$ to precipitation in the Arctic, which is poorly constrained due to the sparse observation network. The difference of precipitation rate in the region among GEOS-5, GPCP, and CMAP was up to a factor of 10. Our model results suggested that the negative bias introduced by doubling the precipitation rate in the Arctic and the positive bias introduced by halving the precipitation rate was similar to the combined effects of flaring emissions and WBF. Although this effect (exaggerated because our method of estimating $\mathrm{BC}_{\text {snow }}$ ) strongly depends on precipitation flux, it is worthwhile to notice the importance of precipitation on $\mathrm{BC}_{\text {snow }}$ simulation.

There remains large uncertainties in flaring emission factors, spatial and temporal variation of flaring emissions, dry deposition velocities of BC, and BC scavenging efficiencies in clouds. Process-specific measurements, particularly in the Arctic, are useful to better constrain the simulation of BC distribution in the region. For example, we need direct measurements of emission factors of gas flares on the western side of the extreme north of Russia, including their spatial and temporal variations. In addition, $v_{\mathrm{d}}$ measurements specific to $\mathrm{BC}$ particles over snow- and ice-covered land surfaces should be made in winter. Measurements of BC scavenging efficiency in clouds, particularly in mixed-phase and ice clouds in the Arctic, are also needed to constrain BC wet deposition. 


\section{Data availability}

The data used in this study are available from the corresponding author upon request (qiling@atmos.ucla.edu).

Acknowledgement. This study was funded by the NASA grant NNX14AF11G from the Atmospheric Chemistry Modeling and Analysis Program (ACMAP). The authors thank Y. Kondo, J. P. Schwarz, S. G. Warren, and H. Liu for helpful discussions. We would also like to thank the Global Monitoring Division at NOAA Earth System Research Laboratory, the Atmospheric Science and Technology Directorate at Environment Canada, and SFT Norway for providing data. The Swedish Environmental Protection Agency and the Swedish Research Council have sponsored BC measurements at Zeppelin. We would also like to thank "Soot In Arctic Snow" group from University of Washington for providing measurements of BC concentrations in snow in the Arctic. We thank the two reviewers for their valuable comments on this manuscript.

Edited by: R. MacKenzie

Reviewed by: A. Stohl and one anonymous referee

\section{References}

Allen, D. J., Kasibhatla, P., Thompson, A. M., Rood, R. B., Doddridge, B. G., Pickering, K. E., Hudson, R. D., and Lin, S. J.: Transport-induced interannual variability of carbon monoxide determined using a chemistry and transport model, J. Geophys. Res.-Atmos., 101, 28655-28669, doi:10.1029/96jd02984, 1996a.

Allen, D. J., Rood, R. B., Thompson, A. M., and Hudson, R. D.: Three-dimensional radon 222 calculations using assimilated meteorological data and a convective mixing algorithm, J. Geophys. Res.-Atmos., 101, 6871-6881, doi:10.1029/95jd03408, 1996b.

Anderson, J. L., Balaji, V., Broccoli, A. J., Cooke, W. F., Delworth, T. L., Dixon, K. W., Donner, L. J., Dunne, K. A., Freidenreich, S. M., Garner, S. T., Gudgel, R. G., Gordon, C. T., Held, I. M., Hemler, R. S., Horowitz, L. W., Klein, S. A., Knutson, T. R., Kushner, P. J., Langenhost, A. R., Lau, N. C., Liang, Z., Malyshev, S. L., Milly, P. C. D., Nath, M. J., Ploshay, J. J., Ramaswamy, V., Schwarzkopf, M. D., Shevliakova, E., Sirutis, J. J., Soden, B. J., Stern, W. F., Thompson, L. A., Wilson, R. J., Wittenberg, A. T., and Wyman, B. L.: The New GFDL Global Atmosphere and Land Model AM2-LM2: Evaluation with Prescribed SST Simulations, J. Climate, 17, 4641-4673, doi:10.1175/jcli-3223.1, 2004.

Arakawa, A. and Schubert, W. H.: Interaction of a $\mathrm{Cu}-$ mulus Cloud Ensemble with the Large-Scale Environment, Part I, J. Atmos. Sci., 31, 674-701, doi:10.1175/15200469(1974)031<0674:ioacce>2.0.co;2, 1974.

Barahona, D., Molod, A., Bacmeister, J., Nenes, A., Gettelman, A., Morrison, H., Phillips, V., and Eichmann, A.: Development of two-moment cloud microphysics for liquid and ice within the NASA Goddard Earth Observing System Model (GEOS-5), Geosci. Model Dev., 7, 1733-1766, doi:10.5194/gmd-7-17332014, 2014.
Barrie, L. A.: First International Conference on Atmospheric Sciences and Applications to Air Quality Arctic air pollution: An overview of current knowledge, Atmos. Environ., 20, 643-663, doi:10.1016/0004-6981(86)90180-0, 1986.

Bergeron, T.: On the physics of clouds and precipitation. Proces Verbaux de l'Association de Météorologie, International Union of Geodesy and Geophysics, Imprimerie Paul Dupont, Paris, France, 156-178, 1935.

Bergin, M. H., Jaffrezo, J. L., Davidson, C. I., Dibb, J. E., Pandis, S. N., Hillamo, R., Maenhaut, W., Kuhns, H. D., and Makela, T.: The contributions of snow, fog, and dry deposition to the summer flux of anions and cations at Summit, Greenland, J. Geophys. Res.-Atmos., 100, 16275-16288, doi:10.1029/95jd01267, 1995.

Bodhaine, B. A.: Barrow Surface Aerosol - 1976-1986, Atmos. Environ., 23, 2357-2369, doi:10.1016/0004-6981(89)90249-7, 1989.

Bond, T. C. and Bergstrom, R. W.: Light Absorption by Carbonaceous Particles: An Investigative Review, Aerosol Sci. Tech., 40, 27-67, doi:10.1080/02786820500421521, 2006.

Bond, T. C., Anderson, T. L., and Campbell, D.: Calibration and Intercomparison of Filter-Based Measurements of Visible Light Absorption by Aerosols, Aerosol Sci. Tech., 30, 582-600, doi:10.1080/027868299304435, 1999.

Bond, T. C., Bhardwaj, E., Dong, R., Jogani, R., Jung, S., Roden, C., Streets, D. G., and Trautmann, N. M.: Historical emissions of black and organic carbon aerosol from energy-related combustion, 1850-2000, Global Biogeochem. Cy., 21, GB2018, doi:10.1029/2006gb002840, 2007.

Bond, T. C., Doherty, S. J., Fahey, D. W., Forster, P. M., Berntsen, T., DeAngelo, B. J., Flanner, M. G., Ghan, S., Kärcher, B., Koch, D., Kinne, S., Kondo, Y., Quinn, P. K., Sarofim, M. C., Schultz, M. G., Schulz, M., Venkataraman, C., Zhang, H., Zhang, S., Bellouin, N., Guttikunda, S. K., Hopke, P. K., Jacobson, M. Z., Kaiser, J. W., Klimont, Z., Lohmann, U., Schwarz, J. P., Shindell, D., Storelvmo, T., Warren, S. G., and Zender, C. S.: Bounding the role of black carbon in the climate system: A scientific assessment, J. Geophys. Res.-Atmos., 118, 5380-5552, doi:10.1002/jgrd.50171, 2013.

Bourgeois, Q. and Bey, I.: Pollution transport efficiency toward the Arctic: Sensitivity to aerosol scavenging and source regions, J. Geophys. Res.-Atmos., 116, D08213, doi:10.1029/2010jd015096, 2011.

Bradbury, J., Clement, Z., and Down, A.: Greenhouse gas emissions and fuel use within the Natural gas supply chain - Sankey Diagram Methodology, Tech. Rep., Quadrennial Energy Review Analysis, Department of Energy, Office of Energy Policy and Systems Analysis, 2015.

Browse, J., Carslaw, K. S., Arnold, S. R., Pringle, K., and Boucher, O.: The scavenging processes controlling the seasonal cycle in Arctic sulphate and black carbon aerosol, Atmos. Chem. Phys., 12, 6775-6798, doi:10.5194/acp-12-6775-2012, 2012.

CAPP: A recommended approach to completing the national pollutant release inventory (NPRI) for the upstream oil and gas industry, Canadian Association of Petroleum Producers (CAPP), available at: http://www.capp.ca/library/publications/ policyRegulatory/pages/pubInfo.aspx?DocId=119572 (last access: 25 November 2016), 2007.

Chen, Y., Li, Q., Randerson, J. T., Lyons, E. A., Kahn, R. A., Nelson, D. L., and Diner, D. J.: The sensitivity of CO and aerosol 
transport to the temporal and vertical distribution of North American boreal fire emissions, Atmos. Chem. Phys., 9, 6559-6580, doi:10.5194/acp-9-6559-2009, 2009.

Chow, J. C., Watson, J. G., Pritchett, L. C., Pierson, W. R., Frazier, C. A., and Purcell, R. G.: The dri thermal/optical reflectance carbon analysis system: description, evaluation and applications in U.S. Air quality studies, Atmos. Environ. A-Gen., 27, 11851201, doi:10.1016/0960-1686(93)90245-T, 1993.

Chow, J. C., Watson, J. G., Chen, L. W. A., Arnott, W. P., Moosmüller, H., and Fung, K.: Equivalence of Elemental Carbon by Thermal/Optical Reflectance and Transmittance with Different Temperature Protocols, Environ. Sci. Technol., 38, 4414-4422, doi:10.1021/es034936u, 2004.

Clarke, A. D. and Noone, K. J.: Soot in the Arctic Snowpack - a Cause for Perturbations in Radiative-Transfer, Atmos. Environ., 19, 2045-2053, doi:10.1016/0004-6981(85)90113-1, 1985.

Clarke, A. D., Noone, K. J., Heintzenberg, J., Warren, S. G., and Covert, D. S.: Aerosol light absorption measurement techniques: Analysis and intercomparisons, Atmos. Environ., 21, 1455-1465, doi:10.1016/0004-6981(67)90093-5, 1987.

Cozic, J., Verheggen, B., Mertes, S., Connolly, P., Bower, K., Petzold, A., Baltensperger, U., and Weingartner, E.: Scavenging of black carbon in mixed phase clouds at the high alpine site Jungfraujoch, Atmos. Chem. Phys., 7, 1797-1807, doi:10.5194/acp-7-1797-2007, 2007.

Delene, D. J. and Ogren, J. A.: Variability of Aerosol Optical Properties at Four North American Surface Monitoring Sites, J. Atmos. Sci., 59, 1135-1150, doi:10.1175/15200469(2002)059<1135:VOAOPA >2.0.CO;2, 2002.

Di Liberto, L., Angelini, F., Pietroni, I., Cairo, F., Di Donfrancesco, G., Viola, A., Argentini, S., Fierli, F., Gobbi, G., Maturilli, M., Neuber, R., and Snels, M.: Estimate of the Arctic Convective Boundary Layer Height from Lidar Observations: A Case Study, Adv. Meteorol., 2012, 851927, doi:10.1155/2012/851927, 2012.

Doherty, S. J., Warren, S. G., Grenfell, T. C., Clarke, A. D., and Brandt, R. E.: Light-absorbing impurities in Arctic snow, Atmos. Chem. Phys., 10, 11647-11680, doi:10.5194/acp-1011647-2010, 2010.

Doherty, S. J., Grenfell, T. C., Forsström, S., Hegg, D. L., Brandt, R. E., and Warren, S. G.: Observed vertical redistribution of black carbon and other insoluble light-absorbing particles in melting snow, J. Geophys. Res.-Atmos., 118, 5553-5569, doi:10.1002/jgrd.50235, 2013.

Dovland, H. and Eliassen, A.: Dry deposition on a snow surface, Atmos. Environ., 10, 783-785, doi:10.1016/0004-6981(76)900809, 1976.

Duan, B., Fairall, C. W., and Thomson, D. W.: Eddy Correlation Measurements of the Dry Deposition of Particles in Wintertime, J. Appl. Meteorol., 27, 642-652, doi:10.1175/15200450(1988)027<0642:ECMOTD>2.0.CO;2, 1988.

Eckhardt, S., Quennehen, B., Olivié, D. J. L., Berntsen, T. K., Cherian, R., Christensen, J. H., Collins, W., Crepinsek, S., Daskalakis, N., Flanner, M., Herber, A., Heyes, C., Hodnebrog, Ø., Huang, L., Kanakidou, M., Klimont, Z., Langner, J., Law, K. S., Lund, M. T., Mahmood, R., Massling, A., Myriokefalitakis, S., Nielsen, I. E., Nøjgaard, J. K., Quaas, J., Quinn, P. K., Raut, J.-C., Rumbold, S. T., Schulz, M., Sharma, S., Skeie, R. B., Skov, H., Uttal, T., von Salzen, K., and Stohl, A.: Current model capabilities for simulating black carbon and sulfate concentra- tions in the Arctic atmosphere: a multi-model evaluation using a comprehensive measurement data set, Atmos. Chem. Phys., 15, 9413-9433, doi:10.5194/acp-15-9413-2015, 2015.

Eleftheriadis, K., Vratolis, S., and Nyeki, S.: Aerosol black carbon in the European Arctic: Measurements at Zeppelin station, Ny-Ålesund, Svalbard from 1998-2007, Geophys. Res. Lett., 36, L02809, doi:10.1029/2008g1035741, 2009.

Elvidge, C. D., Ziskin, D., Baugh, K. E., Tuttle, B. T., Ghosh, T., Pack, D. W., Erwin, E. H., and Zhizhin, M.: A Fifteen Year Record of Global Natural Gas Flaring Derived from Satellite Data, Energies, 2, 595-622, doi:10.3390/en20300595, 2009.

Elvidge, C. D., Baugh, K. E., Ziskin, D., Anderson, S., and Ghosh, T.: Estimation of Gas Flaring Volumes Using NASA MODIS Fire Detection Products, NOAA National Geophysical Data Center (NGDC), annual report, 8, 2011.

Elvidge, C. D., Zhizhin, M., Baugh, K., Hsu, F.-C., and Ghosh, T.: Methods for global survey of natural gas flaring from visible infrared imaging radiometer suite data, Energies, 9, 14, doi:10.3390/en9010014, 2016.

Fan, J., Ghan, S., Ovchinnikov, M., Liu, X., Rasch, P. J., and Korolev, A.: Representation of Arctic mixed-phase clouds and the Wegener-Bergeron-Findeisen process in climate models: Perspectives from a cloud-resolving study, J. Geophys. Res.-Atmos., 116, D00T07, doi:10.1029/2010jd015375, 2011.

Fawole, O. G., Cai, X. M., and MacKenzie, A. R.: Gas flaring and resultant air pollution: A review focusing on black carbon, Environ. Pollut., 216, 182-197, 2016.

Findeisen, W.: Kolloid-meteorologische Vorgänge bei Neiderschlags-bildung, Meteor. Z., 55, 121-133. 1938.

Fisher, J. A., Jacob, D. J., Wang, Q., Bahreini, R., Carouge, C. C., Cubison, M. J., Dibb, J. E., Diehl, T., Jimenez, J. L., Leibensperger, E. M., Lu, Z., Meinders, M. B. J., Pye, H. O. T., Quinn, P. K., Sharma, S., Streets, D. G., van Donkelaar, A., and Yantosca, R. M.: Sources, distribution, and acidity of sulfateammonium aerosol in the Arctic in winter-spring, Atmos. Environ., 45, 7301-7318, doi:10.1016/j.atmosenv.2011.08.030, 2011.

Flanner, M. G.: Arctic climate sensitivity to local black carbon, J. Geophys. Res.-Atmos., 118, 1840-1851, doi:10.1002/jgrd.50176, 2013.

Flanner, M. G., Zender, C. S., Randerson, J. T., and Rasch, P. J.: Present-day climate forcing and response from black carbon in snow, J. Geophys. Res., 112, D11202, doi:10.1029/2006jd008003, 2007.

Flanner, M. G., Zender, C. S., Hess, P. G., Mahowald, N. M., Painter, T. H., Ramanathan, V., and Rasch, P. J.: Springtime warming and reduced snow cover from carbonaceous particles, Atmos. Chem. Phys., 9, 2481-2497, doi:10.5194/acp-9-24812009, 2009.

Flanner, M. G., Liu, X., Zhou, C., Penner, J. E., and Jiao, C.: Enhanced solar energy absorption by internally-mixed black carbon in snow grains, Atmos. Chem. Phys., 12, 4699-4721, doi:10.5194/acp-12-4699-2012, 2012.

Forsström, S., Isaksson, E., Skeie, R. B., Ström, J., Pedersen, C. A., Hudson, S. R., Berntsen, T. K., Lihavainen, H., Godtliebsen, F., and Gerland, S.: Elemental carbon measurements in European Arctic snow packs, J. Geophys. Res.-Atmos., 118, 13614-13627, doi:10.1002/2013jd019886, 2013.

Fukuta, N. and Takahashi, T.: The Growth of Atmospheric Ice Crystals: A Summary of Findings in Vertical Supercooled Cloud Tun- 
nel Studies, J. Atmos. Sci., 56, 1963-1979, doi:10.1175/15200469(1999)056<1963:TGOAIC>2.0.CO;2, 1999.

Gallagher, M. W.: Measurements and parameterizations of small aerosol deposition velocities to grassland, arable crops, and forest: Influence of surface roughness length on deposition, J. Geophys. Res., 107, 4154, doi:10.1029/2001jd000817, 2002.

Garrett, T. J., Zhao, C., and Novelli, P. C.: Assessing the relative contributions of transport efficiency and scavenging to seasonal variability in Arctic aerosol, Tellus B, 62, 190-196, doi:10.1111/j.1600-0889.2010.00453.x, 2010.

Garrett, T. J., Brattström, S., Sharma, S., Worthy, D. E. J., and Novelli, P.: The role of scavenging in the seasonal transport of black carbon and sulfate to the Arctic, Geophys. Res. Lett., 38, L16805, doi:10.1029/2011g1048221, 2011.

Giorgi, F. and Chameides, W. L.: Rainout lifetimes of highly soluble aerosols and gases as inferred from simulations with a general circulation model, J. Geophys. Res.-Atmos., 91, 14367-14376, doi:10.1029/JD091iD13p14367, 1986.

Goldenson, N., Doherty, S. J., Bitz, C. M., Holland, M. M., Light, B., and Conley, A. J.: Arctic climate response to forcing from light-absorbing particles in snow and sea ice in CESM, Atmos. Chem. Phys., 12, 7903-7920, doi:10.5194/acp-12-7903-2012, 2012.

Gronlund, A., Nilsson, D., Koponen, I. K., Virkkula, A., and Hansson, M. E.: Aerosol dry deposition measured with eddycovariance technique at Wasa and Aboa, Dronning Maud Land, Antarctica, Ann. Glaciol., 35, 355-361, 2002.

Hack, J. J.: Parameterization of moist convection in the National Center for Atmospheric Research community climate model (CCM2), J. Geophys. Res.-Atmos., 99, 5551-5568, doi:10.1029/93jd03478, 1994.

Hagler G. S. W., Bergin, M. H., Smith, E. A., and Dibb, J. E.: A summer time series of particulate carbon in the air and snow at Summit, Greenland, J. Geophys. Res., 112, D21309, doi:10.1029/2007JD008993, 2007.

Hallberg, A., Ogren, J. A., Noone, K. J., Heintzenberg, J., Berner, A., Solly, I., Kruisz, C., Reischl, G., Fuzzi, S., Facchini, M. C., Hansson, H. C., Wiedensohler, A., and Svenningsson, I. B.: Phase partitioning for different aerosol species in fog, Tellus B, 44, 545-555, doi:10.1034/j.1600-0889.1992.t01-2-00008.x, 1992.

Hallberg, A., Noone, K. J., Ogren, J. A., Svenningsson, I. B., Flossmann, A., Wiedensohler, A., Hansson, H. C., Heintzenberg, J., Anderson, T. L., Arends, B. G., and Maser, R.: Phase Partitioning of Aerosol Particles in Clouds at Kleiner Feldberg, in: The Kleiner Feldberg Cloud Experiment 1990: EUROTRAC Subproject Ground-Based Cloud Experiment (GCE), edited by: Fuzzi, S., Springer Netherlands, Dordrecht, the Netherlands, 107-127, 1995.

Hansen, J. and Nazarenko, L.: Soot climate forcing via snow and ice albedos, P. Natl. Acad. Sci. USA, 101, 423-428, doi:10.1073/pnas.2237157100, 2004.

He, C., Li, Q. B., Liou, K. N., Zhang, J., Qi, L., Mao, Y., Gao, M., Lu, Z., Streets, D. G., Zhang, Q., Sarin, M. M., and Ram, K.: A global 3-D CTM evaluation of black carbon in the Tibetan Plateau, Atmos. Chem. Phys., 14, 7091-7112, doi:10.5194/acp14-7091-2014, 2014a.

He, C., Li, Q. B., Liou, K. N., Takano, Y., Gu, Y., Qi, L., Mao, Y. H., and Leung, L. R.: Black carbon radiative forcing over the Tibetan Plateau, Geophys. Res. Lett., 41, 7806-7813, doi:10.1002/2014g1062191, 2014b.

He, C., Li, Q., Liou, K.-N., Qi, L., Tao, S., and Schwarz, J. P.: Microphysics-based black carbon aging in a global CTM: constraints from HIPPO observations and implications for global black carbon budget, Atmos. Chem. Phys., 16, 3077-3098, doi:10.5194/acp-16-3077-2016, 2016.

Hegg, D. A., Clarke, A. D., Doherty, S. J., and Ström, J.: Measurements of black carbon aerosol washout ratio on Svalbard, Tellus B, 63, 891-900, doi:10.1111/j.1600-0889.2011.00577.x, 2011.

Held, A., Brooks, I. M., Leck, C., and Tjernström, M.: On the potential contribution of open lead particle emissions to the central Arctic aerosol concentration, Atmos. Chem. Phys., 11, 30933105, doi:10.5194/acp-11-3093-2011, 2011.

Henning, S., Bojinski, S., Diehl, K., Ghan, S., Nyeki, S., Weingartner, E., Wurzler, S., and Baltensperger, U.: Aerosol partitioning in natural mixed-phase clouds, Geophys. Res. Lett., 31, L06101, doi:10.1029/2003gl019025, 2004.

Hillamo, R. E., Kerminen, V. M., Maenhaut, W., Jaffrezo, J. L., Balachandran, S., and Davidson, C. I.: Arctic air, snow and ice chemistrySize distributions of atmospheric trace elements at dye 3, Greenland - I. Distribution characteristics and dry deposition velocities, Atmos. Environ. A-Gen., 27, 2787-2802, doi:10.1016/0960-1686(93)90311-L, 1993.

Hirdman, D., Burkhart, J. F., Sodemann, H., Eckhardt, S., Jefferson, A., Quinn, P. K., Sharma, S., Ström, J., and Stohl, A.: Longterm trends of black carbon and sulphate aerosol in the Arctic: changes in atmospheric transport and source region emissions, Atmos. Chem. Phys., 10, 9351-9368, doi:10.5194/acp-10-93512010, 2010.

Hitzenberger, R., Berner, A., Kromp, R., Kasper-Giebl, A., Limbeck, A., Tscherwenka, W., and Puxbaum, H.: Black carbon and other species at a high-elevation European site (Mount Sonnblick, $3106 \mathrm{~m}$, Austria): Concentrations and scavenging efficiencies, J. Geophys. Res.-Atmos., 105, 24637-24645, doi:10.1029/2000jd900349, 2000.

Hitzenberger, R., Berner, A., Giebl, H., Drobesch, K., KasperGiebl, A., Loeflund, M., Urban, H., and Puxbaum, H.: Black carbon $(\mathrm{BC})$ in alpine aerosols and cloud water - concentrations and scavenging efficiencies, Atmos. Environ., 35, 5135-5141, doi:10.1016/S1352-2310(01)00312-0, 2001.

Huang, K., Fu, J. S., Prikhodko, V. Y., Storey, J. M., Romanov, A., Hodson, E. L., Cresko, J., Morozova, I., Ignatieva, Y., and Cabaniss, J.: Russian anthropogenic black carbon: Emission reconstruction and Arctic black carbon simulation, J. Geophys. Res.Atmos., 120, 11306-11333, doi:10.1002/2015jd023358, 2015.

Huang, L., Gong, S. L., Jia, C. Q., and Lavoué, D.: Importance of deposition processes in simulating the seasonality of the Arctic black carbon aerosol, J. Geophys. Res.-Atmos., 115, D17207, doi:10.1029/2009jd013478, 2010.

Huffman, G. J., Adler, R. F., Morrissey, M. M., Bolvin, D. T., Curtis, S., Joyce, R., McGavock, B., and Susskind, J.: Global Precipitation at One-Degree Daily Resolution from Multisatellite Observations, J. Hydrometeorol., 2, 36-50, doi:10.1175/15257541(2001)002<0036:GPAODD>2.0.CO;2, 2001.

IPCC: Climate Change 2014: Synthesis Report. Contribution of Working Groups I, II and III to the Fifth Assessment Report of the Intergovernmental Panel on Climate Change, edited by: Core 
Writing Team, Pachauri, R. K. and Meyer, L. A., IPCC, Geneva, Switzerland, 151 pp., 2014.

Jacobson, M. Z.: Climate response of fossil fuel and biofuel soot, accounting for soot's feedback to snow and sea ice albedo and emissivity, J. Geophys. Res.-Atmos., 109, D21201, doi:10.1029/2004jd004945, 2004.

Jiao, C., Flanner, M. G., Balkanski, Y., Bauer, S. E., Bellouin, N., Berntsen, T. K., Bian, H., Carslaw, K. S., Chin, M., De Luca, N., Diehl, T., Ghan, S. J., Iversen, T., Kirkevåg, A., Koch, D., Liu, X., Mann, G. W., Penner, J. E., Pitari, G., Schulz, M., Seland, Ø., Skeie, R. B., Steenrod, S. D., Stier, P., Takemura, T., Tsigaridis, K., van Noije, T., Yun, Y., and Zhang, K.: An AeroCom assessment of black carbon in Arctic snow and sea ice, Atmos. Chem. Phys., 14, 2399-2417, doi:10.5194/acp-14-2399-2014, 2014.

Keegan, K. M., Albert, M. R., McConnell, J. R., and Baker, I.: Climate change and forest fires synergistically drive widespread melt events of the Greenland Ice Sheet, P. Natl. Acad. Sci., 111, 7964-7967, 2014.

Koch, D., Menon, S., Del Genio, A., Ruedy, R., Alienov, I., and Schmidt, G. A.: Distinguishing Aerosol Impacts on Climate over the Past Century, J. Climate, 22, 2659-2677, doi:10.1175/2008jcli2573.1, 2009.

Kopacz, M., Mauzerall, D. L., Wang, J., Leibensperger, E. M., Henze, D. K., and Singh, K.: Origin and radiative forcing of black carbon transported to the Himalayas and Tibetan Plateau, Atmos. Chem. Phys., 11, 2837-2852, doi:10.5194/acp-11-28372011, 2011.

Ladd, M. J. and Gajewski, K.: The North American summer Arctic front during 1948-2007, Int. J. Climatol., 30, 874-883, doi:10.1002/joc.1940, 2010.

Li, J. L. F., Waliser, D. E., Chen, W. T., Guan, B., Kubar, T., Stephens, G., Ma, H. Y., Deng, M., Donner, L., Seman, C., and Horowitz, L.: An observationally based evaluation of cloud ice water in CMIP3 and CMIP5 GCMs and contemporary reanalyses using contemporary satellite data, J. Geophys. Res.-Atmos., 117, D16105, doi:10.1029/2012jd017640, 2012.

Lin, S. J. and Rood, R. B.: Multidimensional fluxform semi-Lagrangian transport schemes, Mon. Weather Rev., 124, 2046-2070, doi:10.1175/15200493(1996)124<2046:MFFSLT>2.0.CO;2, 1996.

Liou, K. N., Takano, Y., He, C., Yang, P., Leung, L. R., Gu, Y., and Lee, W. L.: Stochastic parameterization for light absorption by internally mixed BC/dust in snow grains for application to climate models, J. Geophys. Res.-Atmos., 119, 7616-7632, doi:10.1002/2014jd021665, 2014.

Liston, G. E. and Sturm, M.: The role of winter sublimation in the Arctic moisture budget, Hydrol. Res., 35, 325-334, 2004.

Liu, H., Jacob, D. J., Bey, I., and Yantosca, R. M.: Constraints from ${ }^{210} \mathrm{~Pb}$ and ${ }^{7} \mathrm{Be}$ on wet deposition and transport in a global threedimensional chemical tracer model driven by assimilated meteorological fields, J. Geophys. Res.-Atmos., 106, 12109-12128, doi:10.1029/2000jd900839, 2001.

Liu, J., Fan, S., Horowitz, L. W., and Levy, H.: Evaluation of factors controlling long-range transport of black carbon to the Arctic, J. Geophys. Res., 116, D04307, doi:10.1029/2010jd015145, 2011.

Malm, W. C., Sisler, J. F., Huffman, D., Eldred, R. A., and Cahill, T. A.: Spatial and seasonal trends in particle concentration and optical extinction in the United States, J. Geophys. Res.-Atmos., 99, 1347-1370, doi:10.1029/93jd02916, 1994.
Mann, G. W., Carslaw, K. S., Spracklen, D. V., Ridley, D. A., Manktelow, P. T., Chipperfield, M. P., Pickering, S. J., and Johnson, C. E.: Description and evaluation of GLOMAP-mode: a modal global aerosol microphysics model for the UKCA composition-climate model, Geosci. Model Dev., 3, 519-551, doi:10.5194/gmd-3-519-2010, 2010.

Marks, A. A. and King, M. D.: The effects of additional black carbon on the albedo of Arctic sea ice: variation with sea ice type and snow cover, The Cryosphere, 7, 1193-1204, doi:10.5194/tc7-1193-2013, 2013.

McEwen, J. D. N. and Johnson, M. R.: Black carbon particulate matter emission factors for buoyancy-driven associated gas flares, J. Air Waste Manage., 62, 307-321, doi:10.1080/10473289.2011.650040, 2012.

McNaughton, C. S., Clarke, A. D., Freitag, S., Kapustin, V. N., Kondo, Y., Moteki, N., Sahu, L., Takegawa, N., Schwarz, J. P., Spackman, J. R., Watts, L., Diskin, G., Podolske, J., Holloway, J. S., Wisthaler, A., Mikoviny, T., de Gouw, J., Warneke, C., Jimenez, J., Cubison, M., Howell, S. G., Middlebrook, A., Bahreini, R., Anderson, B. E., Winstead, E., Thornhill, K. L., Lack, D., Cozic, J., and Brock, C. A.: Absorbing aerosol in the troposphere of the Western Arctic during the 2008 ARCTAS/ARCPAC airborne field campaigns, Atmos. Chem. Phys., 11, 7561-7582, doi:10.5194/acp-11-7561-2011, 2011.

Moorthi, S. and Suarez, M. J.: Relaxed Arakawa-Schubert - a Parameterization of Moist Convection for General-Circulation Models, Mon. Weather Rev., 120, 978-1002, doi:10.1175/15200493(1992)120<0978:RASAPO>2.0.CO;2, 1992.

Namazi, M., von Salzen, K., and Cole, J. N. S.: Simulation of black carbon in snow and its climate impact in the Canadian Global Climate Model, Atmos. Chem. Phys., 15, 10887-10904, doi:10.5194/acp-15-10887-2015, 2015.

Nilsson, E. D. and Rannik, Ü.: Turbulent aerosol fluxes over the Arctic Ocean: 1. Dry deposition over sea and pack ice, J. Geophys. Res.-Atmos., 106, 32125-32137, doi:10.1029/2000jd900605, 2001.

Overland, J. E. and Turet, P.: Variability of the atmospheric energy flux across $708 \mathrm{~N}$ computed from the GFDL data set. The Polar Oceans and Their Role in Shaping the Global Environment, Geophys. Monogr., No. 84, Amer. Geophys. Union, Washington, D. C., USA, 313-325, 1994.

Park, R. J., Jacob, D. J., Chin, M., and Martin, R. V.: Sources of carbonaceous aerosols over the United States and implications for natural visibility, J. Geophys. Res.-Atmos., 108, 4355, doi:10.1029/2002jd003190, 2003.

Park, R. J., Jacob, D. J., Palmer, P. I., Clarke, A. D., Weber, R. J., Zondlo, M. A., Eisele, F. L., Bandy, A. R., Thornton, D. C., Sachse, G. W., and Bond, T. C.: Export efficiency of black carbon aerosol in continental outflow: Global implications, J. Geophys. Res.-Atmos., 110, D11205, doi:10.1029/2004jd005432, 2005.

Petzold, A., Ogren, J. A., Fiebig, M., Laj, P., Li, S.-M., Baltensperger, U., Holzer-Popp, T., Kinne, S., Pappalardo, G., Sugimoto, N., Wehrli, C., Wiedensohler, A., and Zhang, X.-Y.: Recommendations for reporting "black carbon" measurements, Atmos. Chem. Phys., 13, 8365-8379, doi:10.5194/acp-13-83652013, 2013.

Pozzoli, L., Bey, I., Rast, S., Schultz, M. G., Stier, P., and Feichter, J.: Trace gas and aerosol interactions in the fully coupled model of aerosol-chemistry-climate ECHAM5-HAMMOZ: 
1. Model description and insights from the spring 2001 TRACE-P experiment, J. Geophys. Res.-Atmos., 113, D07308, doi:10.1029/2007jd009007, 2008.

Qi, L., Li, Q., He, C., Wang, X., and Huang, J.: Effects of WegenerBergeron-Findeisen Process on Global Black Carbon Distribution, Atmos. Chem. Phys. Discuss., doi:10.5194/acp-2016-706, in review, 2016.

Quinn, P. K., Bates, T. S., Baum, E., Doubleday, N., Fiore, A. M., Flanner, M., Fridlind, A., Garrett, T. J., Koch, D., Menon, S., Shindell, D., Stohl, A., and Warren, S. G.: Short-lived pollutants in the Arctic: their climate impact and possible mitigation strategies, Atmos. Chem. Phys., 8, 1723-1735, doi:10.5194/acp8-1723-2008, 2008.

Randerson, J. T., Chen, Y., van der Werf, G. R., Rogers, B. M., and Morton, D. C.: Global burned area and biomass burning emissions from small fires, J. Geophys. Res.-Biogeo., 117, G04012, doi:10.1029/2012jg002128, 2012.

Samset, B. H., Myhre, G., Schulz, M., Balkanski, Y., Bauer, S., Berntsen, T. K., Bian, H., Bellouin, N., Diehl, T., Easter, R. C., Ghan, S. J., Iversen, T., Kinne, S., Kirkevåg, A., Lamarque, J.F., Lin, G., Liu, X., Penner, J. E., Seland, Ø., Skeie, R. B., Stier, P., Takemura, T., Tsigaridis, K., and Zhang, K.: Black carbon vertical profiles strongly affect its radiative forcing uncertainty, Atmos. Chem. Phys., 13, 2423-2434, doi:10.5194/acp-13-24232013, 2013.

Schutgens, N. A. J., Gryspeerdt, E., Weigum, N., Tsyro, S., Goto, D., Schulz, M., and Stier, P.: Will a perfect model agree with perfect observations? The impact of spatial sampling, Atmos. Chem. Phys., 16, 6335-6353, doi:10.5194/acp-16-6335-2016, 2016.

Schwarz, J. P., Holloway, J. S., Katich, J. M., McKeen, S., Kort, E. A., Smith, M. L., Ryerson, T. B., Sweeney, C., and Peischl, J.: Black Carbon Emissions from the Bakken Oil and Gas Development Region, Environ. Sci. Technol. Lett., 2, 281-285, doi:10.1021/acs.estlett.5b00225, 2015.

Sellegri, K., Laj, P., Dupuy, R., Legrand, M., Preunkert, S., and Putaud, J. P.: Size-dependent scavenging efficiencies of multicomponent atmospheric aerosols in clouds, J. Geophys. Res.Atmos., 108, 4334, doi:10.1029/2002jd002749, 2003.

Serreze, M. C. and Hurst, C. M.: Representation of Mean Arctic Precipitation from NCEP-NCAR and ERA Reanalyses, J. Climate, 13, 182-201, doi:10.1175/15200442(2000)013<0182:ROMAPF>2.0.CO;2, 2000.

Serreze, M. C., Barry, R. G., and Walsh, J. E.: Atmospheric Water Vapor Characteristics at $70^{\circ} \mathrm{N}$, J. Climate, 8, 719-731, doi:10.1175/1520-0442(1995)008<0719:AWVCA>2.0.CO;2, 1995.

Sharma, S., Lavoué, D., Cachier, H., Barrie, L. A., and Gong, S. L.: Long-term trends of the black carbon concentrations in the Canadian Arctic, J. Geophys. Res.-Atmos., 109, D15203, doi:10.1029/2003jd004331, 2004.

Sharma, S., Andrews, E., Barrie, L. A., Ogren, J. A., and Lavoué, D.: Variations and sources of the equivalent black carbon in the high Arctic revealed by long-term observations at Alert and Barrow: 1989-2003, J. Geophys. Res.-Atmos., 111, D14208, doi:10.1029/2005jd006581, 2006.

Sharma, S., Ishizawa, M., Chan, D., Lavoué, D., Andrews, E., Eleftheriadis, K., and Maksyutov, S.: 16-year simulation of Arctic black carbon: Transport, source contribution, and sensitivity analysis on deposition, J. Geophys. Res.-Atmos., 118, 943-964, doi:10.1029/2012jd017774, 2013.

Shindell, D., and Faluvegi, G.: Climate response to regional radiative forcing during the twentieth century, Nat. Geosci., 2, 294 300, doi:10.1038/ngeo473, 2009.

Slowik, J. G., Cross, E. S., Han, J.-H., Davidovits, P., Onasch, T. B., Jayne, J. T., Williams, L. R., Canagaratna, M. R., Worsnop, D. R., Chakrabarty, R. K., Moosmüller, H., Arnott, W. P., Schwarz, J. P., Gao, R.-S., Fahey, D. W., Kok, G. L., and Petzold, A.: An Inter-Comparison of Instruments Measuring Black Carbon Content of Soot Particles, Aerosol Sci. Tech., 41, 295-314, doi:10.1080/02786820701197078, 2007.

Stier, P., Feichter, J., Kinne, S., Kloster, S., Vignati, E., Wilson, J., Ganzeveld, L., Tegen, I., Werner, M., Balkanski, Y., Schulz, M., Boucher, O., Minikin, A., and Petzold, A.: The aerosol-climate model ECHAM5-HAM, Atmos. Chem. Phys., 5, 1125-1156, doi:10.5194/acp-5-1125-2005, 2005.

Stohl, A.: Characteristics of atmospheric transport into the Arctic troposphere, J. Geophys. Res.-Atmos., 111, D11306, doi:10.1029/2005jd006888, 2006.

Stohl, A., Klimont, Z., Eckhardt, S., Kupiainen, K., Shevchenko, V. P., Kopeikin, V. M., and Novigatsky, A. N.: Black carbon in the Arctic: the underestimated role of gas flaring and residential combustion emissions, Atmos. Chem. Phys., 13, 8833-8855, doi:10.5194/acp-13-8833-2013, 2013.

Stroeve, J. C., Serreze, M. C., Holland, M. M., Kay, J. E., Malanik, J., and Barrett, A. P.: The Arctic's rapidly shrinking sea ice cover: a research synthesis, Climatic Change, 110, 1005-1027, doi:10.1007/s10584-011-0101-1, 2012.

Tedesco, M., Doherty, S., Fettweis, X., Alexander, P., Jeyaratnam, J., and Stroeve, J.: The darkening of the Greenland ice sheet: trends, drivers, and projections (1981-2100), The Cryosphere, 10, 477-496, doi:10.5194/tc-10-477-2016, 2016.

Textor, C., Schulz, M., Guibert, S., Kinne, S., Balkanski, Y., Bauer, S., Berntsen, T., Berglen, T., Boucher, O., Chin, M., Dentener, F., Diehl, T., Easter, R., Feichter, H., Fillmore, D., Ghan, S., Ginoux, P., Gong, S., Grini, A., Hendricks, J., Horowitz, L., Huang, P., Isaksen, I., Iversen, I., Kloster, S., Koch, D., Kirkevå g, A., Kristjansson, J. E., Krol, M., Lauer, A., Lamarque, J. F., Liu, X., Montanaro, V., Myhre, G., Penner, J., Pitari, G., Reddy, S., Seland, $\varnothing .$, Stier, P., Takemura, T., and Tie, X.: Analysis and quantification of the diversities of aerosol life cycles within AeroCom, Atmos. Chem. Phys., 6, 1777-1813, doi:10.5194/acp-6-1777-2006, 2006.

Textor, C., Schulz, M., Guibert, S., Kinne, S., Balkanski, Y., Bauer, S., Berntsen, T., Berglen, T., Boucher, O., Chin, M., Dentener, F., Diehl, T., Feichter, J., Fillmore, D., Ginoux, P., Gong, S., Grini, A., Hendricks, J., Horowitz, L., Huang, P., Isaksen, I. S A., Iversen, T., Kloster, S., Koch, D., Kirkevåg, A., Kristjansson, J. E., Krol, M., Lauer, A., Lamarque, J. F., Liu, X., Montanaro, V., Myhre, G., Penner, J. E., Pitari, G., Reddy, M. S., Seland, Ø., Stier, P., Takemura, T., and Tie, X.: The effect of harmonized emissions on aerosol properties in global models an AeroCom experiment, Atmos. Chem. Phys., 7, 4489-4501, doi:10.5194/acp-7-4489-2007, 2007.

van der Werf, G. R., Randerson, J. T., Giglio, L., Collatz, G. J., Mu, M., Kasibhatla, P. S., Morton, D. C., DeFries, R. S., Jin, Y., and van Leeuwen, T. T.: Global fire emissions and the contribution of deforestation, savanna, forest, agricultural, and peat fires (1997- 
2009), Atmos. Chem. Phys., 10, 11707-11735, doi:10.5194/acp10-11707-2010, 2010.

Verheggen, B., Cozic, J., Weingartner, E., Bower, K., Mertes, S., Connolly, P., Gallagher, M., Flynn, M., Choularton, T., and Baltensperger, U.: Aerosol partitioning between the interstitial and the condensed phase in mixed-phase clouds, J. Geophys. Res.Atmos., 112, D23202, doi:10.1029/2007jd008714, 2007.

Virkkula, A., Ahlquist, N. C., Covert, D. S., Arnott, W. P., Sheridan, P. J., Quinn, P. K., and Coffman, D. J.: Modification, Calibration and a Field Test of an Instrument for Measuring Light Absorption by Particles, Aerosol Sci. Tech., 39, 68-83, doi:10.1080/027868290901963, 2005.

von Schneidemesser, E., Schauer, J. J., Hagler, G. S. W., and Bergin, M. H.: Concentrations and sources of carbonaceous aerosol in the atmosphere of Summit, Greenland, Atmos. Environ., 43, 41554162, doi:10.1016/j.atmosenv.2009.05.043, 2009.

Wang, Q., Jacob, D. J., Fisher, J. A., Mao, J., Leibensperger, E. M., Carouge, C. C., Le Sager, P., Kondo, Y., Jimenez, J. L., Cubison, M. J., and Doherty, S. J.: Sources of carbonaceous aerosols and deposited black carbon in the Arctic in winter-spring: implications for radiative forcing, Atmos. Chem. Phys., 11, 1245312473, doi:10.5194/acp-11-12453-2011, 2011.

Wang, Z. W., Gallet, J. C., Pedersen, C. A., Zhang, X. S., Ström, J., and Ci, Z. J.: Elemental carbon in snow at Changbai Mountain, northeastern China: concentrations, scavenging ratios, and dry deposition velocities, Atmos. Chem. Phys., 14, 629-640, doi:10.5194/acp-14-629-2014, 2014.

Warren, S. G. and Wiscombe, W. J.: Dirty Snow after Nuclear-War, Nature, 313, 467-470, doi:10.1038/313467a0, 1985.

Warren, S. G., Rigor, I. G., Untersteiner, N., Radionov, V. F., Bryazgin, N. N., Aleksandrov, Y. I., and Colony, R.: Snow Depth on Arctic Sea Ice, J. Climate, 12, 1814-1829, doi:10.1175/15200442(1999)012<1814:SDOASI>2.0.CO;2, 1999.

WCRP: Proceedings of the Workshop on the Implementation of the Arctic Precipitation Data Archive (APDA) at the Global Precipitation Climatology Centre (GPCC), Offenbach, Germany, 1012 July, 1996, Arctic Climate System Study, World Climate Research Programme. WCRP-98, WMO/TD 804, 127 pp. plus appendices, 2007, World Climate Research Programme, 7 bis, Avenue de la Paix, Case Postale 2300, 1211 Geneva 2, Switzerland, 1997.
Wegener, A.: Thermodynamik der Atmosphäre, J. A. Barth, Leipzig, Germany, 331 pp., 1911.

Weingartner, E., Saathoff, H., Schnaiter, M., Streit, N., Bitnar, B., and Baltensperger, U.: Absorption of light by soot particles: determination of the absorption coefficient by means of aethalometers, J. Aerosol Sci., 34, 1445-1463, doi:10.1016/S00218502(03)00359-8, 2003.

Wesely, M. L.: Parameterization of surface resistances to gaseous dry deposition in regional-scale numerical models, Atmos. Environ., 23, 1293-1304, doi:10.1016/0004-6981(89)90153-4, 1989.

Wesely, M. L. and Hicks, B. B.: Dry deposition and emission of small particles at the surface of the earth, in: Proceedings Fourth Symposium on Turbulence, Diffusion and Air Quality, 15-18 January 1979, Reno, NV, USA, Am. Meteorol. Soc., Boston, Massachusetts, 510-513, 1979.

Weyant, C. L., Shepson, P. B., Subramanian, R., Cambaliza, M. O. L., Heimburger, A., McCabe, D., Baum, E., Stirm, B. H., and Bond, T. C.: Black Carbon Emissions from Associated Natural Gas Flaring, Environ. Sci. Technol., 50, 2075-2081, doi:10.1021/acs.est.5b04712, 2016.

Wieringa, J.: Representativeness of Wind Observations at Airports, B. Am. Meteorol. Soc., 61, 962-971, doi:10.1175/15200477(1980)061<0962:ROWOAA>2.0.CO;2, 1980.

Xie, P. and Arkin, P. A.: Global Precipitation: A 17Year Monthly Analysis Based on Gauge Observations, Satellite Estimates, and Numerical Model Outputs, B Am. Meteorol. Soc., 78, 2539-2558, doi:10.1175/15200477(1997)078<2539:GPAYMA>2.0.CO;2, 1997.

Zhang, D., Wang, Z., and Liu, D.: A global view of midlevel liquidlayer topped stratiform cloud distribution and phase partition from CALIPSO and CloudSat measurements, J. Geophys. Res.Atmos., 115, D00H13, doi:10.1029/2009JD012143, 2010.

Zhang, L., Gong, S., Padro, J., and Barrie, L.: A size-segregated particle dry deposition scheme for an atmospheric aerosol module, Atmos. Environ., 35, 549-560, doi:10.1016/S13522310(00)00326-5, 2001.

Zhang, Q., Streets, D. G., Carmichael, G. R., He, K. B., Huo, H., Kannari, A., Klimont, Z., Park, I. S., Reddy, S., Fu, J. S., Chen, D., Duan, L., Lei, Y., Wang, L. T., and Yao, Z. L.: Asian emissions in 2006 for the NASA INTEX-B mission, Atmos. Chem. Phys., 9, 5131-5153, doi:10.5194/acp-9-5131-2009, 2009. 